\title{
Differential effects of bivalves on sediment nitrogen cycling in a shallow coastal bay
}

\author{
Ashley Smyth \\ Virginia Institute of Marine Science \\ Anna E. Murphy \\ Virginia Institute of Marine Science \\ Iris C. Anderson \\ Virginia Institute of Marine Science \\ BK Song \\ Virginia Institute of Marine Science
}

Follow this and additional works at: https://scholarworks.wm.edu/vimsarticles

Part of the Biology Commons, Marine Biology Commons, and the Terrestrial and Aquatic Ecology Commons

\section{Recommended Citation}

Smyth, Ashley; Murphy, Anna E.; Anderson, Iris C.; and Song, BK, "Differential effects of bivalves on sediment nitrogen cycling in a shallow coastal bay" (2017). VIMS Articles. 3.

https://scholarworks.wm.edu/vimsarticles/3 


\section{DIFFERENTIAL EFFECTS OF BIVALVES ON SEDIMENT NITROGEN CYCLING IN A SHALLOW COASTAL BAY}

Ashley R. Smyth ${ }^{1+*}$, Anna E. Murphy ${ }^{1}$, Iris C. Anderson ${ }^{1}$, Bongkeun Song ${ }^{1}$

${ }^{1}$ Virginia Institute of Marine Science, School of Marine Science, College of William and Mary, Gloucester Point, Virginia, 23062, USA

${ }^{+}$Present Address: Soil and Water Sciences Department, Tropical Research and Education Center, University of Florida, Homestead, FL 33031, USA

* Corresponding author. E-mail: $\underline{\text { arsmyth@gmail.com }}$

Running head: N Dynamics in Clam Aquaculture and Oyster Reefs

Keywords: denitrification, DNRA, Mercenaria mercenaria, Crassostrea virginica, nitrogen, eutrophication 
Abstract

2 In coastal ecosystems, suspension-feeding bivalves can remove nitrogen though uptake and

3 assimilation or enhanced denitrification. Bivalves may also retain nitrogen through increased

4 mineralization and dissimilatory nitrate reduction to ammonium (DNRA). This study

5 investigated the effects of oyster reefs and clam aquaculture on denitrification, DNRA, and

6 nutrient fluxes $\left(\mathrm{NO}_{x}, \mathrm{NH}_{4}{ }^{+}, \mathrm{O}_{2}\right)$. Core incubations were conducted seasonally on sediments

7 adjacent to restored oyster reefs (Crassostrea virginica), clam aquaculture beds (Mercenaria

8 mercenaria) which contained live clams, and bare sediments from Smith Island Bay, Virginia,

9 USA. Denitrification was significantly higher at oyster reef sediments and clam aquaculture site

10 than bare sediment in the summer; however DNRA was not enhanced. The clam aquaculture site

11 had the highest ammonium production due to clam excretion. While oyster reef and bare

12 sediments exhibited seasonal differences in rate processes, there was no effect of season on

13 denitrification, DNRA or ammonium flux at the clam aquaculture site. This suggests that farm

14 management practices or bivalve metabolism and excretion may override seasonal differences.

15 When water column nitrate concentration was elevated, denitrification increased in clam

16 aquaculture site and oyster reef sediments but not in bare sediment; DNRA was only stimulated

17 at the clam aquaculture site. This, along with a significant and positive relationship between

18 denitrification and sediment organic matter, suggests that labile carbon limited nitrate reduction

19 at the bare sediment site. Bivalve systems can serve as either net sinks or sources of nitrogen to

20 coastal ecosystems, depending mainly on the type of bivalve, location and management

21 practices. 


\section{INTRODUCTION}

Eutrophication, frequently caused by excess nitrogen $(\mathrm{N})$ inputs, affects coastal systems worldwide (Diaz and Rosenberg 2008). Excess N can fuel primary production leading to algal blooms, dead zones, and habitat loss (Paerl 1997, Hauxwell et al. 2001). N can be removed from

27 ecosystems by sediment denitrification, a stepwise reduction pathway of nitrate to dinitrogen gas

$28\left(\mathrm{~N}_{2}\right)$. Modification to the timing and rate of carbon delivery, concentration of nitrate, the terminal

29 electron acceptor, and accumulation of sulfide, may promote dissimilatory nitrate reduction to

30 ammonium (DNRA) instead of denitrification, resulting in $\mathrm{N}$ retention rather than removal

31 (Burgin and Hamilton 2007, Hardison et al. 2015). DNRA and denitrification compete for nitrate

32 produced via nitrification, the oxidation of ammonium to nitrate/nitrite, or supplied directly from

33 the water column. The potential for coastal systems to remove $\mathrm{N}$ and combat the negative

34 consequences of eutrophication relies in part on the competition between these two nitrate

35 reducing processes.

36 There is growing interest in using shellfish to mitigate the effects of eutrophication and

37 manage N pollution (Bricker et al. 2014, Kellogg et al. 2014, Rose et al. 2014). Suspension

38 feeding bivalves such as oysters and clams, provide top-down control of phytoplankton biomass

39 and enhance sediment N cycling through benthic-pelagic coupling (Dame et al. 1984, Newell

40 2004, Smyth et al. 2013a, Murphy et al. 2016a). These organisms can also serve as habitat for

41 nitrifying and denitrifying bacteria (Welsh and Castadelli 2004, Stief 2013, Welsh et al. 2015).

42 As bivalves feed, particulate $\mathrm{N}$ contained in phytoplankton and other organic matter is removed

43 from the water column. A portion of this $\mathrm{N}$ is assimilated, of which a fraction is excreted as

44 dissolved $\mathrm{N}$ directly to the water column; the remainder is egested as biodeposits and transferred

45 to the sediments. $\mathrm{N}$ in the biodeposits can be buried or utilized by the microbial community (e.g. 
remineralized, assimilated, nitrified) and may enhance denitrification (Newell et al. 2002,

47 Kellogg et al. 2013, Smyth et al. 2013a). Additionally, the delivery of organic carbon to the sediments in biodeposists may stimulate DNRA, which is favored over denitrification in high

49 carbon and low nitrate conditions (Tiedje 1988, Burgin and Hamilton 2007, Hardison et al. 50 2015).

To date, evidence of the effectiveness for bivalves to control $\mathrm{N}$ availability is equivocal

52 (Table 1). The amount of $\mathrm{N}$ that is recycled rather than removed seems to depend on species,

53 environmental characteristics and grow-out practices. For example, commercial hard clam

54 (Mercenaria mercenaria) aquaculture in a shallow polyhaline tributary of Chesapeake Bay

55 contributed to reduced conditions in the sediments and accumulation of sulfide, which resulted in

$56 \mathrm{~N}$ regeneration via DNRA rather than removal via denitrification (Murphy et al. 2016a).

57 However, in the highly eutrophied Po River Delta (Italy) sediments from clam (Tapes

58 philippinarum) aquaculture sites had higher rates of denitrification than DNRA (Nizzoli et al.

59 2006). Oyster (Crassostrea virginica) reefs tended to increase denitrification relative to bare sites

60 (Piehler and Smyth 2011, Smyth et al. 2013b, Kellogg et al. 2013, Humphries et al. 2016) but

61 had a minimal influence on sediment $\mathrm{N}$ cycling in eutrophic systems (Hoellein and Zarnoch

62 2014). The majority of studies on oyster reefs have focused on denitrification and estimates of

63 DNRA are limited (Table 1). Based on the few studies which are available, denitrification is

64 favored over DNRA in oyster reef sediments and sediments affected by oysters, either adjacent

65 to oyster reefs or floating aquaculture cages, tended to have higher rates of DNRA than bare

66 sediment (Smyth et al. 2013b, Erler et al. 2017).

Within the same ecosystem, the effects of bivalves on sediment biogeochemistry will

68 likely differ based on the type of bivalve, growing conditions and physical substrates that can be 
69 colonized by denitrifying and nitrifying bacteria. For example, in Chesapeake Bay, the largest

70 estuary in the US, clams (Mercenaria mercenaria) and oysters (Crassostrea virginica) are the

71 predominate bivalve species. Clams may enhance nitrification by supplying ammonium and

72 increasing $\mathrm{O}_{2}$ penetration depth through bioturbation, leading to more coupled nitrification-

73 denitrification (Pelegrí and Blackburn 1994, Welsh 2003, Nizzoli et al. 2006). Additionally, the

74 shell, soft tissue and digestive system can be colonized by nitrifying and denitrifying bacteria

75 and these areas exhibited high rates of these processes (Welsh and Castadelli 2004, Stief 2013,

76 Welsh et al. 2015). However, in an aquaculture context some of the natural function of clams

77 may be impacted by the method of cultivation. In the Chesapeake Bay region, the high density of

78 clams and use of predator exclusion nets, which restrict clam movement, modify water flow and

79 serve as habitat for macroalgae, may affect exchanges at the sediment-water interface (Secrist

80 2013). The predator exclusion net is a plastic netting placed flush to the sediment surface (over

81 the clams) and held in place with reinforcing bars and sandbags. Macroalgae grows rapidly using

82 the $\mathrm{NH}_{4}{ }^{+}$generated by from the clams requires periodic removal (Murphy et al. 2015). The

83 predator exclusion net and the high density of may contribute to greater organic enrichment of

84 sediment (Newell 2004), resulting in reduced and sulfidic conditions that promote DNRA

85 (Murphy et al. 2016a). While natural clam beds still exists in the US, clam aquaculture is

86 becoming a more common feature in the coastal landscape (Murphy et al. 2016b, Emery 2015).

87 Oysters reefs have dramatically declined in area in coastal ecosystems due to factors such

88 as disease and over-fishing (Beck et al. 2011). Oysters are sessile, epifanual suspension feeding

89 bivalves that form biogenic reefs. The three-dimensional reef structure on top of the sediment

90 helps concentrate organic matter on the sediment surface. The reef structure increases

91 biogeochemical cycling compared to unstructured sediment (Smyth et al. 2016) and provides 
92 habitat and refugia for diverse infaunal and epifaunal communities, which include many

93 bioturbating organisms (Kellogg et al. 2013). While the reef structure alone can increase

94 biogeochemical cycling, the oysters can have a direct impact on nitrogen cycling. Filtration and

95 associated biodepostion delivers organic $\mathrm{C}$ and $\mathrm{N}$ to the sediments, leading to elevated rates of

96 nitrogen cycling compared to bare sediment (Newell et al. 2002, Kellogg et al. 2013, Smyth et al.

97 2013a). At the same time, the oysters add ammonium directly through excretion and consume

98 oxygen through respiration (Kellogg et al. 2013, Smyth et al. 2013a). Additionally, the shell and

99 gut of oysters can serve as habitat for nitrifying and denitrifying bacteria (Caffrey et al. 2016).

100 Clam aquaculture and oyster reefs have been shown to affect both DNRA and denitrification

101 relative to bare sediments in a variety of coastal systems (Table 1); however, few studies have

102 measured both processes simultaneously. Given the different ecological features between clam

103 aquaculture and oyster reefs, it is expected that the effect of these organisms on benthic

104 metabolism and nitrogen cycling would be different.

105 As aquaculture continues to expand, there is competition for available space with oyster

106 reef restoration efforts, since the range of conditions tolerated by clams and oysters is similar. In

107 order to aid in the evaluation of ecosystem services provided by clam aquaculture and oyster reef

108 restoration, we assessed sediment $\mathrm{N}$ dynamics at a restored oyster reef (C. virginica) and clam

109 aquaculture site (M. mercenaria). Specifically, we investigated the relative importance of DNRA

110 and denitrification in sediments adjacent to a restored oyster reef and from a clam aquaculture

111 bed as well as a reference bare subtidal flat (bare site) sediment, seasonally in Smith Island Bay,

112 Virginia, USA. We hypothesized that sediments from oyster reefs and clam aquaculture would

113 enhance microbial $\mathrm{N}$ cycling activity compared to the bare site due to increased $\mathrm{C}$ and $\mathrm{N}$ delivery

114 to the sediments through bivalve biodeposition. We expected restored oyster reef sediments to 
115 have higher rates of denitrification than sediments from clam aquaculture sites, but that clam

116 aquaculture sites would have greater DNRA than oyster reef sediments because of the high clam

117 density and the use of predator exclusion nets that enhance organic matter accumulation.

118 Additionally, we expected seasonal differences in rate processes associated with temperature and 119 food availability for the bivalves.

\section{MATERIALS AND METHODS}

\section{Study site and field sample collection}

122 To determine how clam aquaculture and oyster reefs affect sediment $\mathrm{N}$ cycling, sediment

123 samples were collected from a clam aquaculture site which contained littleneck clams $(3.5 \mathrm{~cm}$ to

$1245.2 \mathrm{~cm}$ long) and from sediment adjacent to a restored oyster reef in Smith Island Bay, VA

$125\left(37^{\circ} 08^{\prime} 57.08^{\prime \prime} \mathrm{N}, 75^{\circ} 53^{\prime} 06.81^{\prime \prime} \mathrm{W}\right)$. Smith Island is one of the southern barrier islands of the

126 Delmarva Peninsula and part of the Virginia Coastal Reserve Long Term Ecological Research

127 site (VCR LTER; Fig 1). Smith Island Bay has an average water depth of $0.4 \mathrm{~m}$, semidiurnal

128 tides that range about $1.2 \mathrm{~m}$ and a residence time from 4-12 days (Safak et al. 2015). Sampling

129 sites included (1) a restored oyster reef located on an intertidal flat, (2) a clam aquaculture bed,

130 which is part of a commercial aquaculture lease with predator exclusion nets and (3) a bare

131 subtidal flat (bare site) located approximately $50 \mathrm{~m}$ from the reef and aquaculture operation.

132 Smith Island Bay was selected for this study because both clam aquaculture and restored oyster

133 reefs are found within close proximity to each other. Samples were taken for sediment

134 biogeochemical flux experiments and sediment physico-chemical properties (sediment organic

135 matter, benthic microalgal biomass and pore-water nutrients) seasonally in April, July, and

$136 \quad$ November 2014. 


\section{Continuous Flow Incubations}

Continuous flow core incubations were used to examine rates of $\mathrm{N}$ exchanges at the

139 sediment-water interface. Triplicate sediment cores $(9.5 \mathrm{~cm}$ inner diameter x $10 \mathrm{~cm}$ sediment

140 depth) were collected by hand from each of the three sampling sites. Sediment samples from the

141 oyster reef were collected adjacent to the reef and did not contain live oysters. For samples from

142 the clam aquaculture site, the predator exclusion net was removed prior to sample collection.

143 Associated infauna were left undisturbed for all samples; therefore, if present, live clams were

144 not removed from the sediment cores collected at the clam aquaculture site. Water chemistry was

145 assessed at the site with a YSI 6600 datasonde, (YSI, Inc., Yellow Springs, OH, USA).

146 Approximately 170 L of water were collected from Smith Island Bay for use in the continuous

147 flow core incubations and for dissolved nutrient analyses.

Upon collection, sediment cores and water were transported to an environmental chamber

149 set to in situ temperature at the Virginia Institute of Marine Science (VIMS) in Gloucester Point,

150 Virginia, USA. At VIMS, cores were submerged in aerated site water and held in the dark for 12-

$15116 \mathrm{hrs}$. The following day each core was sealed with a gas tight lid equipped with inflow and

152 outflow ports and incubated in a continuous flow system (Gardner and McCarthy 2009).

153 Unfiltered, aerated site water was passed over the cores at a flow rate of $3 \mathrm{ml}$ per minute. Dark

154 conditions were maintained throughout the course of the incubation to reduce the effects of

155 photosynthetic algae (An and Joye 2001)and to prevent the formation of bubbles that affect

156 dissolved gas concentrations (Reeburgh 1969).

157 Cores were acclimated for 24 hours before sampling to allow the system to reach steady

158 state. Samples for dissolved nutrients (combined nitrate/nitrate $\left(\mathrm{NO}_{\mathrm{x}}\right)$ and ammonium $\left(\mathrm{NH}_{4}^{+}\right)$)

159 and gasses $\left(\mathrm{O}_{2}\right.$ and $\left.\mathrm{Ar}\right)$ were collected three times over the course of 24 hours after the initial 
160 pre-incubation period. A bypass line that flowed from the replacement water tank directly into

161 the sample vial and not through a core tube was used to determine the concentration of dissolved

162 constituents entering the cores. After the initial 24-hour sampling period, replacement water was

163 enriched with ${ }^{15} \mathrm{~N}-\mathrm{NaNO}_{3}(98 \mathrm{~atm} \%$ ) to a final concentration of $\sim 100 \mu \mathrm{mol} \mathrm{L}-1$ for isotopic

164 pairing experiments (Nielsen 1992, Risgaard-Petersen et al. 1995, Yin et al. 2014). After a 24-

165 hour equilibration period, samples were collected three times over the following 24-hours to

166 measure DNRA and denitrification. At the end of the 4-day experiment average outflow oxygen

167 concentration ranged from $4.8 \pm 0.15 \mathrm{mg} / 1 \mathrm{O}_{2}(69 \%$ of saturation $)$ in the summer to $7.8 \pm 0.9$

$168 \mathrm{mg} / 1 \mathrm{O}_{2}(91 \%$ of saturation) in the fall.

169 Sediment physico-chemical properties

170 Upon completion of the flux incubations, clams were removed and counted. The upper 2

$171 \mathrm{~cm}$ of sediment were homogenized and analyzed for sediment organic matter (SOM), determined

172 by loss on ignition $(n=3)$. Sediments were dried for 24 hours at $60^{\circ} \mathrm{C}$ then combusted at $525^{\circ} \mathrm{C}$

173 for 4 hours. The difference between the weights of dried and combusted samples constituted

174 SOM, expressed as a percentage of the total sediment mass. Pore-water $(n=3)$ was collected in

175 the field from the clam aquaculture site, bare sediment and oyster reef sediment using a stainless

176 steel push-point sampler (2 cm screen; MHE Products, East Tawas, MI, USA), inserted 5-7 cm

177 into the sediment. Pore-water nutrient samples were immediately filtered $(0.45 \mu \mathrm{m}$ Whatman

178 polyethersulfone) and frozen until analysis for dissolved inorganic nitrogen (DIN). Pore-water

179 sulfide samples were immediately fixed with zinc acetate and analyzed on a spectrophotometer

180 within a week of collection (Cline 1969). Sediment samples for benthic chlorophyll $a$, a proxy

181 for algal biomass $(n=3)$, were collected at the clam aquaculture site, bare sediment and oyster

182 reef adjacent sediment from the upper $0.3 \mathrm{~cm}$ of sediment using a cut-off syringe (1.1 cm ID) and 
183 stored frozen until analysis. Samples for sediment chlorophyll $a$ were extracted with $10 \mathrm{ml}$ of

$18490 \%$ ethanol, sonicated for 30 seconds and extracted at $-15^{\circ} \mathrm{C}$ for 24 hours. Benthic algal

185 biomass was determined using spectrophotometry (Lorenzen 1967), modified to include the

186 extraction of the sediment in $10 \mathrm{ml}$ of solvent (Pinckney et al. 1994). Samples for pore-water and

187 benthic chlorophyll $a$, were collected prior to removing the predator exclusion net at the clam

188 aquaculture site.

\section{Analytical Methods and Calculations}

Samples for nutrient analysis were immediately filtered through a $0.45 \mu \mathrm{m}$ Whatman

192 polyethersulfone (PES) filter and frozen until analysis. Filtrate was analyzed with a Lachat

193 Quick-Chem 8000 (Lachat Instruments, Milwaukee, WI, USA) automated ion analyzer for $\mathrm{NO}_{\mathrm{x}}$

194 (combined $\mathrm{NO}_{3}{ }^{-}$and $\mathrm{NO}_{2}{ }^{-}$) and $\mathrm{NH}_{4}{ }^{+}$. Detection limits for $\mathrm{NO}_{\mathrm{x}}$ and $\mathrm{NH}_{4}{ }^{+}$were 0.20 and 0.36

$195 \mu \mathrm{M}$, respectively.

Samples for dissolved gasses were collected by filling $12 \mathrm{ml}$ Exetainer vials from the

197 bottom up. Vials were allowed to overflow by several volumes before being preserved with 100

$198 \mu \mathrm{L}$ of saturated $\mathrm{ZnCl}_{2}$. Exetainers were capped and stored underwater below collection

199 temperature until analysis for dissolved gasses $\left(\mathrm{O}_{2},{ }^{29} \mathrm{~N}_{2},{ }^{30} \mathrm{~N}_{2}\right.$, Ar $)$ on a membrane inlet mass

200 spectrometer (MIMS) (Kana et al. 1994, An et al. 2001). An inline furnace was added to the

201 MIMS for ${ }^{29} \mathrm{~N}_{2}$ and ${ }^{30} \mathrm{~N}_{2}$ samples to increase precision and remove $\mathrm{O}_{2}$ which can lead to

202 overestimation of denitrification (Lunstrum and Aoki 2016). Samples for DNRA $\left({ }^{15} \mathrm{NH}_{4}{ }^{+}\right)$were

203 filtered through a $0.45 \mu \mathrm{m}$ Whatman polyethersulfone (PES) filter and frozen until analysis using

204 the OX/MIMS method (Yin et al. 2014). The OX/MIMS method uses hypobromite iodine

205 solution to oxidize ${ }^{15} \mathrm{NH}_{4}{ }^{+}$to ${ }^{29} \mathrm{~N}_{2}$ or ${ }^{30} \mathrm{~N}_{2}$, and concentrations of both isotopic species were 
206 determined on the MIMS with an inline furnace (Yin et al. 2014). The production of ${ }^{29} \mathrm{~N}_{2}$ and

$207{ }^{30} \mathrm{~N}_{2}$ associated with the hypobromite oxidation of ${ }^{15} \mathrm{NH}_{4}{ }^{+}$was calculated by difference between

208 paired oxidized and unoxidized samples, including those from the bypass line.

209 Fluxes were calculated as:

$$
J=\left(\left[i_{\text {outflow }}\right]-\left[i_{\text {inflow }}\right]\right) \times \frac{F}{A}
$$

211 where $\left[i_{\text {oufflow }}\right]$ and $\left[i_{\text {inflow }}\right]$ are the concentrations $(\mu \mathrm{M})$ of dissolved constituents leaving and 212 entering the core, respectively; $F$ is the peristaltic pump flow rate $\left(3 \mathrm{ml} \mathrm{min}^{-1}\right)$; and $A$ is the 213 surface area of the core $\left(\mathrm{m}^{2}\right)$. A positive flux indicates release from the sediment to the water 214 column while a negative flux represents uptake from the water column by the sediment. Negative $215 \mathrm{O}_{2}$ fluxes are expressed as sediment oxygen demand (SOD). Denitrification of ambient ${ }^{14} \mathrm{NO}_{3}{ }^{-}$ $216\left(D_{14}\right)$ and added ${ }^{15} \mathrm{NO}_{3}{ }^{-}\left(D_{15}\right)$ were calculated using the isotope pairing technique equations 217 (Nielsen 1992):

$$
\mathrm{D}_{14}=\mathrm{D}_{15} \times(\mathrm{p} 29 / 2 \mathrm{p} 30)
$$

220 where p29 and p30 are production rates of ${ }^{29} \mathrm{~N}_{2}$ and ${ }^{30} \mathrm{~N}_{2}$, respectively. In an ecosystem such as 221 Smith Island Bay, where ambient water column $\mathrm{NO}_{\mathrm{x}}{ }^{-}$is low (less than $1 \mu \mathrm{M}$ ) relative to the 222 experimentally-added ${ }^{15} \mathrm{~N}-\mathrm{NaNO}_{3}(\sim 100 \mu \mathrm{M}), \mathrm{D}_{15}$ is considered the potential denitrification rate 223 or the capacity of the sediments to denitrify when $\mathrm{NO}_{\mathrm{x}}$ is provided in excess. Rates of 224 denitrification utilizing nitrate in the water $\left(D_{w}\right)$ were calculated based on the concentration $(\mu M)$ 225 of ${ }^{15} \mathrm{NO}_{3}{ }^{-}$relative to ${ }^{14} \mathrm{NO}_{3}{ }^{-}$in the inflow water, times $\mathrm{D}_{15}$ using the following equation:

$$
\mathrm{D}_{\mathrm{w}}=\left(\left[{ }^{14} \mathrm{NO}_{3}{ }^{-}\right] /\left[{ }^{15} \mathrm{NO}_{3}{ }^{-}\right]\right) * \mathrm{D}_{15}
$$

227 Denitrification supported by nitrate produced through nitrification in the sediments $\left(D_{n}\right)$ was 228 calculated by the difference between $\mathrm{D}_{14}$ and $\mathrm{D}_{\mathrm{w}}$ (Nielsen 1992). We did not account for 
229 incomplete denitrification resulting in $\mathrm{N}_{2} \mathrm{O}$ production or $\mathrm{N}_{2}$ production from anammox.

230 Potential rates of DNRA (DNRA 15 ) were determined as ${ }^{15} \mathrm{NH}_{4}{ }^{+}$production (An and Gardner

231 2002). The concentration of ${ }^{15} \mathrm{NH}_{4}{ }^{+}$was determined from the total ${ }^{15} \mathrm{~N}_{2}$ produced after

232 hyprobromite oxidation as described by Yin et al. (2014). Ambient DNRA (DNRA 14 ) was

233 calculated based on the assumption that the relative rates of DNRA utilizing ${ }^{15} \mathrm{NO}_{3}{ }^{-}$and ${ }^{14} \mathrm{NO}_{3}{ }^{-}$

234 occur at the same ratio as denitrification (Risgaard-Petersen et al. 1995):

$$
\mathrm{DNRA}_{14}=\mathrm{DNRA}_{15} *\left(\mathrm{D}_{14} / \mathrm{D}_{15}\right)
$$

236 DNRA, based on $\mathrm{NO}_{3}{ }^{-}$from the water column $\left(\mathrm{DNRA}_{\mathrm{w}}\right)$, was calculated using the ratio of ${ }^{14} \mathrm{NO}_{3}$

237 to ${ }^{15} \mathrm{NO}_{3}$ concentration. Rates of DNRA coupled to sediment nitrification $\left(\mathrm{DNRA}_{\mathrm{n}}\right)$ were

238 estimated from $D_{N R A_{w}}$ and the ratio between $D_{n}$ and $D_{w}$ (Risgaard-Petersen et al. 1995).

239 Nitrification rates were calculated as the sum of ambient denitrification $\left(\mathrm{D}_{14}\right)$, ambient

240 DNRA (DNRA $\left.{ }_{14}\right)$, and $\mathrm{NO}_{\mathrm{x}}{ }^{-}$effluxes:

$$
\text { Nitrification }=\text { Positive } \mathrm{NO}_{\mathrm{x}} \text { flux }+\mathrm{D}_{14}+\mathrm{DNRA}_{14}
$$

242 DNRA measurements are considered conservative because we did not extract $\mathrm{NH}_{4}{ }^{+}$from the

243 sediment and only calculated for ammonium fluxing to the water column (i.e. DNRA is in the

244 sediment not the overlying water) (Bruesewitz et al. 2013). Since nitrification rates are calculated

245 from DNRA, these are also conservative.

\section{Statistical analysis}

248 Mixed effects models were used to examine the interactive effects of site (oyster reef sediment,

249 clam aquaculture sediment, bare sediment) and season for nutrient fluxes, $\mathrm{D}_{14}, \mathrm{D}_{15}, \mathrm{DNRA}_{14}$,

$250 \mathrm{DNRA}_{15}$, and SOM. The mixed effects model (lme function from the 'nlme' package) consisted

251 of a random effect of number of bivalves in sediment cores, to account for the fact that a random 
252 number of clams were included in samples from the clam aquaculture site and no oysters were

253 included in oyster reef samples, and fixed effect of site and season. Benthic chlorophyll $a$, pore-

254 water DIN and $\mathrm{H}_{2} \mathrm{~S}$, which were collected from the field, were also analyzed with a linear model

255 but did not include number of clams ( $g l s$ function from the 'nlme' package). Tukey HSD post-

256 hoc analysis was used to compare means when an effect was significant. A mixed effects model

257 was also used to compare ambient and potential rates (i.e. $\mathrm{D}_{15}$ to $\mathrm{D}_{14}$ as well as $\mathrm{DNRA}_{15}$ to

258 DNRA $_{14}$ ) measured from the same core in each season, followed by Tukey HSD post-hoc

259 analysis. Linear regressions were used to assess the relationship between sediment oxygen

260 demand (SOD) or sediment organic matter (SOM) and nitrate reduction rates, calculated

261 nitrification and nutrient fluxes across all sites and seasons. Pearson correlation coefficients were

262 also calculated. Assumptions of normality and homogeneity were tested using Shapiro-Wilkes

263 and Levene's tests, respectively. Logarithmic or Box-Cox transformations were preformed if

264 necessary to meet assumptions of analyses. All analyses were considered significant at the $265 \mathrm{p}<0.05$ level.

266 RESULTS

\section{Site Characteristics}

268 Water temperatures, salinity and dissolved nutrient concentrations varied between

269 seasons at Smith Island Bay (Table 2). Over the course of the study, water temperature ranged

270 from $14^{\circ} \mathrm{C}$ to $25^{\circ} \mathrm{C}$, with the highest temperature in summer and lowest in fall. Salinity was

271 relatively consistent, varying by 3 units over the course of the study. $\mathrm{NH}_{4}^{+}$concentration ranged

272 from $0.45 \mu \mathrm{M}$ to $3.06 \mu \mathrm{M}$, with the highest concentration in the spring. $\mathrm{NO}_{\mathrm{x}}$ concentration was

273 less than $\mathrm{NH}_{4}{ }^{+}$for all seasons and only detectable in the fall when concentration was $0.72 \mu \mathrm{M}$.

274 Dissolved oxygen (DO), measured around mid-day, was always above $90 \%$ sat. and ranged from 
$2756.36 \mathrm{mg} / 1$ (91.5\% sat. ) in the summer to $8.05 \mathrm{mg} / 1$ (98.1\% sat.) in the spring for Smith Island 276 Bay (Table 2).

277 Pore-water $\mathrm{NO}_{\mathrm{x}}$ was similar across seasons (Table 3; $\left.\mathrm{p}=0.424\right)$ and between sites (Table

$2783 ; \mathrm{p}=0.419)$. There was no seasonal effect on pore-water $\mathrm{NH}_{4}^{+}$(Table $\left.3 ; \mathrm{p}=0.098\right)$ but there were

279 site differences (Table 3; $\mathrm{p}=0.001$ ). Pore-water $\mathrm{NH}_{4}{ }^{+}$concentration was higher at the clam

280 aquaculture site compared to bare sediment (Tukey HSD; $\mathrm{p}=0.001$ ) and oyster reef sediment

281 (Tukey HSD; $\mathrm{p}=0.002$ ). Pore-water $\mathrm{H}_{2} \mathrm{~S}$ varied seasonally (Table 3; $\mathrm{p}=0.012$ ), with the highest

282 concentration in the summer but there were no differences between sites $(\mathrm{p}=0.092)$. SOM, varied

283 between the sites (Table $3 ; \mathrm{p}=0.005$ ) and was significantly higher at the oyster reef and clam

284 aquaculture site compared to the bare sediment (Tukey HSD; $\mathrm{p}=0.001, \mathrm{p}=0.001$, respectively).

285 The interaction between site and season affected benthic chlorophyll $a(\mathrm{p}=<0.001)$. Sediment

286 chlorophyll $a$ was higher in the fall compared to the spring and summer for each site (Table 3).

287 The sediment cores from the clam aquaculture site contained different numbers of clams, ranging

288 from 0 to 4 . There were 0 clams present in cores collected from the clam aquaculture site in the

289 summer, 4 clams in each core collected during the fall, in the spring two cores contained 3 clams

290 and one core contained 4 clams (Supplemental Table 1).

\section{$291 \quad$ Nitrate Reduction Rates}

292 Denitrification $\left(\mathrm{D}_{14}\right)$ rates showed a significant interaction between site and season

$293(\mathrm{p}<0.001)$. Oyster reef sediments had higher $\mathrm{D}_{14}$ in the summer compared to spring and fall, clam

294 bed sediments showed no difference among seasons and the bare sediment exhibited a sequential

295 decline from spring, summer, to fall (Figure 2). There were also differences between the sites

296 within each season. During the summer, $\mathrm{D}_{14}$ was highest in sediments from oyster reef sediment

297 and lowest at the bare sediment with clam aquaculture site having an intermediate rate. In the 
298 fall, $\mathrm{D}_{14}$ at the clam aquaculture site was higher than the bare sediment and oyster reef sediment 299 but in the spring there were no differences between the sites.

300 In contrast to $\mathrm{D}_{14}, \mathrm{DNRA}_{14}$ showed a significant difference between sites $(\mathrm{p}=0.045)$ and 301 season ( $p=0.026$; Figure 2), with no significant interaction ( $p=0.830)$. $\mathrm{DNRA}_{14}$ was similar in the 302 spring and fall (Tukey HSD, $\mathrm{p}=0.47$ ) but higher in the fall compared to the summer (Tukey 303 HSD, $\mathrm{p}=0.021$ ). Overall, $\mathrm{DNRA}_{14}$ was not significantly enhanced at the clam aquaculture site or 304 oyster reef sediment compared to the bare sediment (Tukey HSD, $p=0.219,0.601$, respectively) 305 but $\mathrm{DNRA}_{14}$ at the clam aquaculture site was significantly higher than the oyster reef sediment 306 (Tukey HSD, $\mathrm{p}=0.038$ ). For all sites, $\mathrm{D}_{14}$ was at least 3 times greater than $\mathrm{DNRA}_{14}$ (Fig 2a). The 307 majority of $\mathrm{D}_{14}$ and $\mathrm{DNRA}_{14}$ was coupled to nitrification (Figure 2); $\mathrm{D}_{\mathrm{n}}$ ranged from $94.7 \%$ of 308 total nitrate reduction at the oyster reef sediment in the fall to $99.8 \%$ of total nitrate reduction 309 from the bare sediment in the spring. DNRA followed a similar pattern, with nitrification 310 accounting for more than $95 \%$ of the nitrate used for DNRA.

311 Potential nitrate reduction rates $\left(\mathrm{D}_{15}\right.$ plus $\left.\mathrm{DNRA}_{15}\right)$ (i.e. when nitrate was experimentally

312 added) exhibited similar patterns to ambient nitrate reduction ( $\mathrm{D}_{14}$ plus $\mathrm{DNRA}_{14}$ ) rates. Potential

313 denitrification $\left(D_{15}\right)$ showed a significant interaction between site and season $(p<0.001$, Figure

3143 ). For the oyster reef sediment $D_{15}$ was significantly higher in the summer than the spring or

315 fall. This was also true for the bare sediment. The clam aquaculture site, $\mathrm{D}_{15}$ was highest in the 316 summer but not significantly different compared to the other seasons. During the summer, the 317 oyster reef sediment had the highest $\mathrm{D}_{15}\left(75.23 \pm 18.51 \mu \mathrm{mol} \mathrm{N} \mathrm{m} \mathrm{hr}^{-1}\right)$. This was also the 318 overall highest $\mathrm{D}_{15}$. In the other seasons, the clam aquaculture site had the highest $\mathrm{D}_{15}$. $\mathrm{D}_{15}$ was 319 higher than $\mathrm{DNRA}_{15}$ for all sites and seasons (Figure 3). DNRA 15 was affected by both site $320(\mathrm{p}=0.042)$ and season $(\mathrm{p}=0.034) . \mathrm{DNRA}_{15}$ was highest in the fall and lowest in the summer, with 
321 spring having an intermediate rate. Mean $\mathrm{DNRA}_{15}$ was higher (3.8 times) at the clam aquaculture

322 site compared to the oyster reef sediment and 3.7 times higher than bare sediment, but the

323 increase was only significant for the clam aquaculture site compared to the oyster reef sediment

324 (Tukey HSD, $\mathrm{p}=0.04$ ). $\mathrm{DNRA}_{15}$ was not different at the clam aquaculture site (Tukey HSD, $325 \mathrm{p}=0.191$ ) or oyster reef sediment (Tukey HSD, $\mathrm{p}=0.640$ ) compared to the bare sediment. The 326 highest $\mathrm{D}_{15}$ did not correspond to the highest $\mathrm{DNRA}_{15}$.

$327 \mathrm{D}_{15}$ was higher than $\mathrm{D}_{14}(\mathrm{p}<0.001)$ and $\mathrm{DNRA}_{15}$ was higher than $\mathrm{DNRA}_{14}(\mathrm{p}<0.001)$.

328 This indicates nitrate reduction increased with water column nitrate; however, the magnitude of

329 this increase was site dependent. $\mathrm{D}_{15}$ significantly increased compared to $\mathrm{D}_{14}$ at the oyster reef

330 sediment (Tukey HSD, $\mathrm{p}<0.001$ ) and clam aquaculture site (Tukey HSD; $\mathrm{p}=0.005$ ), while $\mathrm{D}_{14}$

331 and $\mathrm{D}_{15}$ at the bare site were not significantly different from each other (Tukey HSD, $\mathrm{p}=0.173$ ).

332 This indicates that denitrification was limited by nitrate at the bivalve sites but not at the bare

333 site. The response of DNRA to nitrate addition was less than denitrification, with the largest

334 increase observed at the clam aquaculture site. The clam aquaculture site was the only site where

335 DNRA $_{15}$ was significantly higher than $\mathrm{DNRA}_{14}$ (Tukey HSD, $\mathrm{p}<0.001$ ).

\section{Nutrient Fluxes}

337 The largest efflux of both $\mathrm{NH}_{4}{ }^{+}$and $\mathrm{NO}_{\mathrm{x}}$ was observed from the clam aquaculture site, in 338 the spring and in the summer, respectively (Table 4). $\mathrm{NO}_{\mathrm{x}}$ fluxes were affected by site $(\mathrm{p}=0.006)$ 339 and season $(\mathrm{p}=0.001)$ and the interaction was not significant $(\mathrm{p}=0.050)$. All sites had a positive

$340 \mathrm{NO}_{\mathrm{x}}$ flux during the summer, resulting in summer fluxes being different from the spring (Tukey

341 HSD; $p=0.009$ ) and fall (Tukey HSD; $\mathrm{p}=0.009$ ). $\mathrm{NO}_{\mathrm{x}}$ fluxes were higher at the clam aquaculture 342 site compared to the bare sediment (Tukey HSD; $\mathrm{p}=0.005$ ) but the $\mathrm{NO}_{\mathrm{x}}$ flux from the oyster reef 
343 sediment was not significantly different compared to the bare sediment (Tukey HSD; $p=0.072$ )

344 or the clam aquaculture site (Tukey HSD; $\mathrm{p}=0.42$ ).

345 The interaction between site and season was significant for $\mathrm{NH}_{4}{ }^{+}$fluxes $(\mathrm{p}<0.001)$. The

346 clam aquaculture site was the only site to have an efflux of $\mathrm{NH}_{4}{ }^{+}$during each season and rates

347 were not significantly different between seasons (Tukey HSD; $p=0.081$ (fall-spring), $p=0.795$

348 (fall-summer), $\mathrm{p}=0.247$ (spring-summer). Oyster reef sediments had the highest $\mathrm{NH}_{4}{ }^{+}$flux in the

349 summer compared to the spring (Tukey HSD; $p<0.001$ ) and fall (Tukey HSD; $p<0.001$ ). At the

350 bare site, $\mathrm{NH}_{4}{ }^{+}$fluxes were positive in the summer and spring and significantly different from

351 the negative fluxes observed in the fall (Tukey HSD; $p<0.001 \& p<0.001$, respectively). During

352 the summer $\mathrm{NH}_{4}{ }^{+}$fluxes were similar between all the sites but during the spring and fall, $\mathrm{NH}_{4}{ }^{+}$

353 flux from the clam aquaculture site was significantly higher than either the oyster reef sediment

354 (Tukey HSD; $\mathrm{p}<0.001$ (spring), $\mathrm{p}=0.001$ (fall)) or bare sediment (Tukey HSD; $\mathrm{p}=0.007$ (spring),

$355 \mathrm{p}<0001$ (fall)). Calculated nitrification rates ranged from $1.54 \pm 0.42 \mu \mathrm{mol} \mathrm{N} \mathrm{m}{ }^{-2} \mathrm{hr}^{-1}$ at the bare

356 site during the fall to $18.25 \pm 3.68 \mu \mathrm{mol} \mathrm{N} \mathrm{m}^{-2} \mathrm{hr}^{-1}$ in the oyster reef during the summer (Table

357 4). The interaction between site and season was significant for nitrification rates $(\mathrm{p}=0.03)$.

358 Nitrification rates were similar across all seasons for the clam aquaculture site and bare sediment

359 but higher in the summer compared to the spring (Tukey HSD; $\mathrm{p}=0.004$ ) or fall (Tukey HSD;

$360 \mathrm{p}=0.002)$ for the oyster reef sediment. Nitrification was similar between the sites in the spring

361 but the clam aquaculture site was higher than the bare sediment (Tukey HSD; $\mathrm{p}=0.019$ ) and

362 slightly higher than the oyster reef (Tukey HSD; $\mathrm{p}=0.048$ ) in the fall, while nitrification at the

363 oyster reef was slightly higher than the bare sediment (Tukey HSD; $\mathrm{p}=0.005$ ) and similar to the

364 clam aquaculture site (Tukey HSD; $\mathrm{p}=0.130$ ) in the summer. 
There were both seasonal $(\mathrm{p}<0.001)$ and site $(\mathrm{p}=0.020)$ differences in SOD, but the

366 interaction was not significant $(\mathrm{p}=0.105)$. The lowest $\operatorname{SOD}\left(324.75 \pm 23.19 \mu \mathrm{mol} \mathrm{O} \mathrm{m}^{-2} \mathrm{hr}^{-1}\right)$

367 was measured from the bare sediment during the fall. The clam aquaculture site had the highest

368 SOD $\left(1883.69 \pm 368.06 \mu \mathrm{mol} \mathrm{O} \mathrm{m}^{-2} \mathrm{hr}^{-1}\right)$, measured during the spring (Table 4). SOD was

369 higher in the oyster reef sediment and clam aquaculture site compared to the bare sediments

370 (Table 4), however the only significant increase was between the bare sediment and the clam

371 aquaculture site (Tukey HSD; $p=0.021$ ). SOD across all of the sites was significantly lower in

372 the fall compared to the spring (Tukey HSD; $\mathrm{p}<0.001$ ) and summer (Tukey HSD; $<<0.001$ ).

\section{Correlations}

SOD was significantly and positivity related to total ambient nitrate reduction $(\mathrm{p}=0.017)$,

375 calculated nitrification $(\mathrm{p}=0.019)$, and $\mathrm{NH}_{4}{ }^{+}$flux $(\mathrm{p}=0.015)$. SOD explained $21 \%$ of the variance

376 in total ambient nitrate reduction, calculated as the sum of $\mathrm{DNRA}_{14}$ plus $\mathrm{D}_{14}, 17 \%$ of the

377 variance in calculated nitrification and $31 \%$ of the variance in $\mathrm{NH}_{4}{ }^{+}$flux (Figure 4). SOM also

378 explained $10 \%$ of the variance in $\mathrm{DNRA}_{14}$ and $20 \%$ of the variance in $\mathrm{D}_{14}$ (Figure 5 ). $\mathrm{D}_{14}$ was

379 significantly and positively correlated with $\mathrm{SOM}(\mathrm{p}=0.018)$. $\mathrm{DNRA}_{14}$ was positively correlated

380 with SOM but this relationship was not significant $(\mathrm{p}=0.107)$.

\section{Discussion}

Clam aquaculture and restored oyster reefs enhanced $\mathrm{N}$ transformations via their effect on

383 sediment carbon and nitrification. N cycling pathways were related to SOD (Figure 4) and SOM

384 controlled denitrification (Figure 5). These relationships indicate the importance of carbon

385 availability as a predictor of nitrate reduction in the oligotrophic Smith Island Bay ecosystem

386 (Eyre et al. 2013). While carbon availability contributes to the differences between the sites, the

387 high percent of nitrate reduction, coupled to nitrification (both $\mathrm{DNRA}_{n}$ and $\mathrm{D}_{\mathrm{n}}$ were greater than 
$95 \%$ of $\mathrm{DNRA}_{14}$ and $\mathrm{D}_{14}$ ), indicates the importance of nitrification as a source of nitrate for all

389 sites.

Previous studies have attributed increased rates of $\mathrm{N}$ cycling processes in sediments

391 associated with bivalves to high organic matter loading due to biodeposition, high surface area of

392 the oyster reef substrate compared to bare sediment, bioturbation activity and gut and shell

393 biofilm communities and, when present, excretion by the animals themselves (Newell et al.

394 2002, Smyth et al. 2013a, Kellogg et al. 2014, Welsh et al. 2015). Given the higher SOM at the

395 clam aquaculture site and oyster reef sediment compared to the subtidal bare sediment,

396 biodeposition of labile organic carbon likely contributed to the observed enhanced

397 denitrification. In addition, because denitrification rates increased with added $\mathrm{NO}_{3}{ }^{-}$at the bivalve

398 sites but not at the bare sediment, we conclude $\mathrm{NO}_{3}{ }^{-}$also limited denitrification at bivalve sites.

399 In contrast, denitrification rates were not primarily limited by $\mathrm{NO}_{3}{ }^{-}$at the bare sediment

400 locations, which may be more strongly driven by organic $\mathrm{C}$, anoxic conditions, or microbial

401 community structure.

402 While oyster reef sediments and clam aquaculture sites increase denitrification compared

403 to the bare sediment, the effect varied seasonally and was dependent on bivalve species. The

404 largest bivalve effect on denitrification was observed at the oyster reef sediment in the summer.

405 During the spring and fall, denitrification was enhanced more at the clam aquaculture site than

406 the oyster reef sediment. In contrast, there were no seasonal differences within the clam

407 aquaculture site, suggesting farm management practices may override seasonal effects. The

408 seasonal differences possibly associated with variation in the bivalve response to food

409 availability (i.e. filtration rates). In warmer months when seston is high, oysters tend to increase

410 biodeposit production while clams decrease clearance rates (Langdon and Newell 1989, Hawkins 
411 et al. 1998, Newell et al. 2005). However, there were no clams inside the sediment cores in the

412 summer. Since denitrification associated with the clam shells, gut and gills, which can be very

413 important (Welsh and Castadelli 2004) was unaccounted for during this time and these

414 measurements may be an underestimate.

415 When assessing the role of bivalves for enhanced $\mathrm{N}$ removal through denitrification, it is

416 important to consider the magnitude of $\mathrm{N}$ removal versus $\mathrm{N}$ recycling. Overall, denitrification

417 efficiency $\left(\mathrm{D}_{14} /\left(\mathrm{D}_{14}+\mathrm{NO}_{\mathrm{x}}+\mathrm{NH}_{4}{ }^{+}\right)\right)$was $15 \%, 47 \%$ and $66 \%$, in the clam aquaculture site, bare

418 sediment and oyster reef sediment, respectively. The lower efficiency at the clam aquaculture

419 site is associated with increased ammonium flux. DNRA accounted for less than $10 \%$ of the total

$420 \mathrm{NH}_{4}{ }^{+}$efflux and is unlikely responsible for the enhanced ammonium flux. Rather, the high

421 ammonium efflux at the clam aquaculture site may be due to microbial mineralization as well as

422 direct excretion of $\mathrm{NH}_{4}{ }^{+}$by the clams. The difference between the oyster reef sediment and clam

423 aquaculture site is due in part to the fact that live oysters were not included in oyster reef

424 samples. Denitrification efficiency at the oyster reef would likely be lower and nitrogen

425 regeneration would be higher if live oysters were included with the sediment, as excretion from

426 live oysters is also source of $\mathrm{NH}_{4}{ }^{+}$(Smyth et al. 2013a, Caffrey et al. 2016).

427 Bivalves can have a disproportionally large effect on nitrogen cycling relative to the area.

428 For example, oyster reefs only occupy $2.7 \%$ of the area in Bogue Sound, North Carolina yet

429 remove $4 \%$ of the estimated annual nitrogen load through enhanced denitrification (Smyth et al.

430 2013b). Restoration of oyster reefs in Maryland could remove about half of the external nitrogen

431 inputs (Kellogg et al. 2013) and 26\% of $\mathrm{N}$ inputs into Ninigret Pond, Rhode Island could be

432 removed if 5\% of the estuary was used for oyster aquaculture (Humphries et al. 2016). However,

433 nitrogen regeneration associated with bivalves can also be disproportionately high relative to the 
434 aerial coverage of the bivalves. Clam aquaculture occupies $3 \%$ of the subtidal bottom in

435 Cherrystone Inlet, Virginia but nitrogen regeneration is equal to about half of the watershed

436 nitrogen load (Murphy et al. 2016b). Similarly, at a mussel farm in Sacca di Goro, Italy, mussels

437 covered only $5 \%$ of the area but excretion accounted for $25 \%$ of total DIN regeneration in the

438 system (Nizzoli et al. 2011). Density is one of the main factors that determines whether bivalves

439 are nitrogen sources or sinks at the ecosystem scale. High densities of bivalves tend to decrease

440 denitrification and increase nitrogen regeneration due to excretion and organic matter loading to

441 the sediments (Newell 2004). The exact density of bivalves that increases nitrogen regeneration

442 and decreases denitrification depends on hydrodynamics and sediment quality. To extrapolate

443 rates from experiments to the ecosystem scale assumes that processes scale linearly with density.

444 We did not capture denitrification directly related to the oyster microbiome itself or account for

445 oyster excretion. Therefore, extrapolating rates from our experiment may underestimate the

446 overall impact of bivalves on $\mathrm{N}$ cycling. More work is needed to determine ways to evaluate the

447 effect of bivalves on processes at the ecosystem scale.

448 In addition to direct modification of $\mathrm{N}$ pools and fluxes, bivalves can affect $\mathrm{O}_{2}$

449 availability. The clam aquaculture site had the highest SOD, which coincided with a larger

450 ammonium efflux. The correlation between SOD and ammonium production for bare sediment

451 and oyster reef sediment reflects demand of oxygen to support nitrification and aerobic

452 decomposition. When live clams are present, SOD also incorporates clam respiration (Murphy et

453 al. 2016a). Thus, clams are major sinks for oxygen and sources of $\mathrm{N}$, in addition to being sites

454 for nitrification and denitrification (Welsh et al. 2015, Benelli et al. 2017).

455 As observed in other oligotrophic systems with low nutrients, biodeposition enhances

456 denitrification. Biodeposits are a carbon source and accumulation on the sediment decreases the 
oxygen penetration depth and diffusive pathway for water column nitrate, leading to increased

458 fluxes (Caffrey et al. 1993, Smyth et al. 2015). However, there is likely a threshold above which

459 the addition of organic matter from bivalves increases SOD and no longer stimulates

460 denitrification (Newell et al. 2005, Hoellein and Zarnoch 2014, Humphries et al. 2016). This

461 threshold depends on competition for oxygen, which limits nitrification rates and impacts nitrate

462 availability as well as denitrifier abundance and sediment redox conditions. Higher SOD is

463 indicative of increased organic matter oxidation or higher nitrification (Caffrey et al. 1993,

464 Fulweiler et al. 2008); however, a high SOD is also related to sediment anoxia, as the abiotic

465 oxidation of reduced compounds such as sulfide consume oxygen. Because of the relationship

466 between SOD and nitrate reduction, we conclude that carbon deposition is driving nitrate

467 reduction, particularly at the bivalve sites. The relationship between total nitrate reduction and

468 SOD reflects the complicated relationship between nitrate availability, $\mathrm{O}_{2}$ and carbon for

469 controlling nitrate reduction.

470 As expected based on the environmental conditions of Smith Island (i.e. low water

471 column nitrate concentrations, high flow and an oxygenated water column), the majority (>95\%)

472 of nitrate reduction measured in this study was supported by $\mathrm{NO}_{3}{ }^{-}$from nitrification $\left(\mathrm{D}_{\mathrm{n}}\right.$ and

473 DNRAn $_{n}$, Figure 2). The bivalve sites had higher rates of nitrification than the bare sediment,

474 possibly due to organic matter loading and/or ample $\mathrm{NH}_{4}{ }^{+}$supply. Although nitrification is a

475 chemolithoautotrophic process, which does not rely on organic matter, small amounts of organic

476 matter loading increase nitrification (Caffrey et al. 1993). The mineralization of this organic

477 matter serves as a source of $\mathrm{NH}_{4}{ }^{+}$to the nitrifying community. However, high SOM, and

478 subsequent increase in SOD, can lead to oxygen limitation for nitrification and the highest rates

479 of nitrification occur at intermediate concentrations of both ammonium and oxygen (Caffrey et 
481 ammonium-oxidizing archaea (AOA), which are mixotrophs that require a carbon source, rather

482 than ammonium-oxidizing bacteria (AOB). are responsible for nitrification (Qin et al. 2014).

483 The experimental addition of $\mathrm{NO}_{3}{ }^{-}$significantly enhanced denitrification rates in both the 484 clam aquaculture site and oyster reef sediments (i.e. $\mathrm{D}_{15}>\mathrm{D}_{14}$ ). The increase in denitrification 485 with increased $\mathrm{NO}_{3}{ }^{-}$in the water column suggests denitrification was $\mathrm{NO}_{3}^{-}$-limited rather than 486 carbon limited at both bivalve sediments. The increase in denitrification at the bivalve sites 487 supports the hypothesis that bivalve biodeposition supplies organic carbon for $\mathrm{NO}_{3}{ }^{-}$reduction. At 488 the bare sediment, both DNRA and denitrification were ultimately limited by carbon availability 489 or potentially, microbial metabolic capacity since the experimental $\mathrm{NO}_{3}{ }^{-}$addition had no effect 490 on denitrification or DNRA

491 Higher water column $\mathrm{NO}_{3}{ }^{-}$can alleviate the competition between DNRA and 492 denitrification and enhance both processes (Roberts et al. 2012) (Koop-Jakobsen and Giblin 493 2010). However, in our study, the stimulatory effect of $\mathrm{NO}_{3}{ }^{-}$addition on DNRA was minimal 494 and only observed at the clam aquaculture site (Figure 3). The fact that $\mathrm{NO}_{3}{ }^{-}$stimulated DNRA at 495 the clam aquaculture site may be due to differences in the microbial community structure 496 compared to bare sediment. In a nearby tributary, clam aquaculture sediments had significantly 497 higher abundances of DNRA communities compared with bare sediments based on the 498 quantification of cytochrome C nitrite reductase genes ( $n r f A$ ) (Murphy et al. 2016a). But, despite 499 the increase in DNRA at the clam aquaculture site, the relative importance of DNRA to total $500 \mathrm{NO}_{3}{ }^{-}$reduction was unaffected by the added $\mathrm{NO}_{3}^{-}$. A similar trend has been observed in salt 501 marsh ecosystems (Koop-Jakobsen and Giblin 2010) where the addition of nitrate alleviated 502 competition between DNRA and denitrification for nitrate from nitrification and allowed both 
503 processes to increase. Yet, when water column nitrate increased, the ratio of carbon to $\mathrm{NO}_{3}{ }^{-}$

504 shifted because of increased $\mathrm{NO}_{3}{ }^{-}$, conditions which favor denitrification resulting in higher

505 denitrification than DNRA(Burgin and Hamilton 2007). The $\mathrm{NO}_{3}{ }^{-}$addition lowered the ratio of

506 organic carbon to $\mathrm{NO}_{3}{ }^{-}$, resulting in more energetically favorable conditions for denitrification

507 compared to DNRA (Burgin and Hamilton 2007).

508 Based on recent studies examining $\mathrm{N}$ cycling in clam aquaculture sites and oyster habitats in a

509 tributary of Chesapeake Bay that show that DNRA exceeds denitrification (Murphy et al. 2016a,

510 Lunstrum et al. 2017), it was expected that biodeposition would favor DNRA over

511 denitrification. However, this was not observed in our study; rather, we found denitrification

512 exceeded DNRA and rates of DNRA were lower than those reported previously. Moreover,

513 unlike other studies, DNRA was not affected by clam aquaculture or oysters although slightly

514 higher DNRA was observed in the clam aquaculture site compared to the oyster reef sediment.

515 The availability of nitrate from nitrification maintains conditions that favor denitrification

516 despite the higher SOM at the at clam aquaculture site and restored oyster reefs (Tiedje 1988,

517 Burgin and Hamilton 2007). Differences between our data and previous published studies

518 highlight the fact that the effects of bivalves on sediment biogeochemistry is site specific. More

519 studies are necessary to fully understand how environmental conditions drive the effect of

520 bivalves on $\mathrm{N}$ dynamics.

521 The inclusion of live bivalves in sediment cores can drastically alter benthic nitrogen

522 cycling (Kellogg et al. 2013, Smyth et al. 2013a, Turek and Hoellein 2015, Humphries et al.

523 2016, Murphy et al. 2016a). While there are advantages to including live bivalves in experiment

524 chambers, especially oysters, which build complex reef ecosystems, it is logistically challenging

525 (Humphries et al. 2016). Our study focused on how oyster reefs and clam aquaculture affect $\mathrm{N}$ 
526 dynamics at the sediment-water interface. By sampling sediments from the oyster reef and

527 omitting the oyster reef itself, we may underestimate the effects of oyster reef ecosystems. The

528 random sampling of clam aquaculture sites resulted in an unequal number of clams in each core.

529 The clams were not removed to prevent altering the natural biogeochemical gradients in the

530 sediments, which are critical to maintain realistic conditions during the incubations. By chance

531 no clams were contained in the summer sediment cores. To account for this, we analyzed our

532 data using a mixed effects model, which allows for variation due to the number of bivavles

533 present. While the current study used sediments from clam aquaculture sites and restored oyster

534 reefs to investigate the effects of these bivalves on sediment $\mathrm{N}$ cycling, studies wishing to

535 compare bivalves would benefit from including a known number of bivalves in experimental

536 chambers.

537

538 Conclusion

539 Understanding how clam aquaculture and oyster reefs affect sediment $\mathrm{N}$ cycling is

540 important when assessing the use of bivalves as management tools for controlling eutrophication.

541 While oyster reefs and clam aquaculture can enhance $\mathrm{N}$ removal compared to reference

542 sediments, certain conditions may result in net $\mathrm{N}$ regeneration. Clam aquaculture, which utilize a

543 predator exclusion net in ecosystems with low water column nitrate and short residence time may

544 be a source of new $\mathrm{N}$ from mineralization and excretion (Murphy et al. 2016b). The high efflux

$545 \mathrm{of} \mathrm{NH}_{4}{ }^{+}$at the clam aquaculture site is due in part to the presence of live bivalves in the sediment

546 cores, indicating the direct control that infaunal bivalves and their associated microbiota have on

547 overall benthic flux and $\mathrm{N}$ cycle process rates. Conversion of bare sediment to oyster reefs,

548 would, likely have a similar effect, where oyster reefs enhance sediment denitrification relative 
549 to bare sediment and where the shell can be colonized by denitrifying bacteria but the addition of

550 live oysters to the ecosystem may increase ammonium regeneration through excretion and $\mathrm{N}$

551 regeneration (Kellogg et al. 2013, Smyth et al. 2013a). Factors such as location, hydrodynamics,

552 species, growing conditions and sediment redox condition likely affect whether the addition of

553 bivalves will remove or enhance $\mathrm{N}$. As $\mathrm{N}$ loading and bivalve aquaculture and oyster reef

554 restoration continue to expand in shallow coastal ecosystems, understanding what conditions

555 yield removal of $\mathrm{N}$ compared to recycling is important for determining the efficacy of bivalves in 556 controlling $\mathrm{N}$ pollution.

\section{ACKNOWLEDGEMENTS}

559 We thank Edward Smith, Sean Fate, Hunter Walker, Martha Murphy, Ann Arfkin, Jennifer

560 Stanhope, Cay Thompson and PG Ross for field and laboratory assistance. This research was

561 financially supported by the National Science Foundation (NSF-OCE-1321373), Virginia Coast

562 Reserve Long Term Ecological Research (NSF-DEB-1237733, 0621014), and the David H.

563 Smith Conservation Research Postdoctoral Fellowship. Comments from Tim Hoellein and three

564 anonymous reviewers greatly improved this manuscript. This is contribution \#XXXX from the

565 Virginia Institute of Marine Science. 
REFERENCES

An, S., and S. B. Joye. 2001. Enhancement of coupled nitrification-denitrification by benthic photosynthesis in shallow estuarine sediments. Limnology and Oceanography 46:62-74.

An, S., and W. S. Gardner. 2002. Dissimilatory nitrate reduction to ammonium (DNRA) as a nitrogen link, versus denitrification as a sink in a shallow estuary (Laguna Madre/Baffin Bay, Texas). Marine Ecology Progress Series 237:41-50.

An, S., W. S. Gardner, and T. Kana. 2001. Simultaneous Measurement of Denitrification and Nitrogen Fixation Using Isotope Pairing with Membrane Inlet Mass Spectrometry Analysis. Applied and Environmental Microbiology 67:1171-1178.

Beck, M. W., R. D. Brumbaugh, L. Airoldi, A. Carranza, L. D. Coen, C. Crawford, O. Defeo, G. J. Edgar, B. Hancock, M. C. Kay, H. S. Lenihan, M. W. Luckenbach, C. L. Toropova, G. Zhang, and X. Guo. 2011. Oyster Reefs at Risk and Recommendations for Conservation, Restoration, and Management. BioScience 61:107-116.

Benelli, S., M. Bartoli, E. Racchetti, P. C. Moraes, M. Zilius, I. Lubiene, and E. A. Fano. 2017. Rare but large bivalves alter benthic respiration and nutrient recycling in riverine sediments. Aquatic Ecology 51:1-16.

Blackburn, T. H. 1996. Nitrogen gas flux from sediments: insights from simulation modelling. Aquatic Microbial Ecology 10:209-211.

Bricker, S. B., K. C. Rice, and O. P. Bricker. 2014. From Headwaters to Coast: Influence of Human Activities on Water Quality of the Potomac River Estuary. Aquatic Geochemistry 20:291-323.

Bruesewitz, D. A., W. S. Gardner, R. F. Mooney, L. Pollard, and E. J. Buskey. 2013. Estuarine ecosystem function response to flood and drought in a shallow, semiarid estuary: Nitrogen cycling and ecosystem metabolism. Limnology and Oceanography 58:2293-2309.

Burgin, A. J., and S. K. Hamilton. 2007. Have we overemphasized the role of denitrification in aquatic ecosystems? A review of nitrate removal pathways. Frontiers in Ecology and the Environment 5:89-96.

Caffrey, J. M., J. T. Hollibaugh, and B. Mortazavi. 2016. Living oysters and their shells as sites of nitrification and denitrification. Marine Pollution Bulletin 112:86-90.

Caffrey, J. M., N. P. Sloth, H. F. Kaspar, and T. H. Blackburn. 1993. Effect of organic loading on nitrification and denitrification in a marine sediment microcosm. FEMS Microbiology Ecology 12:159-167.

Cline, J. D. 1969. Spectrophotometric Determination of Hydrogen Sulfide in Natural Waters. Limnology and Oceanography 14:454-458. 
Dame, R. F., R. G. Zingmark, and E. Haskin. 1984. Oyster reefs as processors of estuarine materials. Journal of Experimental Marine Biology and Ecology 83:239-247.

Diaz, R. J., and R. Rosenberg. 2008. Spreading Dead Zones and Consequences for Marine Ecosystems. Science (New York, N.Y.) 321:926-929.

Emery, K. A. 2015. Coastal bivalve aquaculture carbon cycling, spatial distribution and resource use in Virginia, USA and Baja California, Mexico.

Erler, D. V., D. T. Welsh, W. W. Bennet, T. Meziane, C. Hubas, D. Nizzoli, and A. J. P. Ferguson. 2017. The impact of suspended oyster farming on nitrogen cycling and nitrous oxide production in a sub-tropical Australian estuary. Estuarine, Coastal and Shelf Science 192:117-127.

Eyre, B. D., D. T. Maher, and P. Squire. 2013. Quantity and quality of organic matter (detritus) drives $\mathrm{N}_{2}$ effluxes (net denitrification) across seasons, benthic habitats, and estuaries. Global Biogeochemical Cycles 27:1083-1095.

Fulweiler, R. W., S. W. Nixon, B. A. Buckley, and S. L. Granger. 2008. Net Sediment N 2 Fluxes in a Coastal Marine System Experimental Manipulations and a Conceptual Model. Ecosystems 11:1168-1180.

Gardner, W. S., and M. J. McCarthy. 2009. Nitrogen dynamics at the sediment water interface in shallow, sub-tropical Florida Bay: why denitrification efficiency may decrease with increased eutrophication. Biogeochemistry 95:185-198.

Hardison, A. K., C. K. Algar, A. E. Giblin, and J. J. Rich. 2015. Influence of organic carbon and nitrate loading on partitioning between dissimilatory nitrate reduction to ammonium (DNRA) and $\mathrm{N}_{2}$ production. Geochimica et Cosmochimica Acta 164:146-160.

Hauxwell, J., J. Cebri n, C. Furlong, and I. Valiela. 2001. Macroalgal canopies contribute to eelgrass (Zostera marina) decline in temperate estuarine ecosystems. Ecology 82:10071022.

Hawkins, A., R. Smith, S. H. Tan, and Z. B. Yasin. 1998. Suspension-feeding behavior in tropical bivalve molluscs: Perna viridis, Crassostrea belcheri, Crassostrea iradelei, Saccostrea cucculata and Pinctada margarifera. Marine Ecology Progress ... 166:173-185.

Hoellein, T. J., and C. B. Zarnoch. 2014. Effect of eastern oysters (Crassostrea virginica) on sediment carbon and nitrogen dynamics in an urban estuary. Ecological Applications 24:271-286.

Humphries, A. T., S. G. Ayvazian, J. C. Carey, B. T. Hancock, S. Grabbert, D. Cobb, C. J. Strobel, and R. W. Fulweiler. 2016. Directly Measured Denitrification Reveals Oyster Aquaculture and Restored Oyster Reefs Remove Nitrogen at Comparable High Rates. Frontiers in Marine Science 3:107-10. 
635

636

637

638

639

640

641

642

643

644

645

646

647

648

649

650

651

652

653

654

655

656

657

658

659

660

661

662

663

664

665

666

667

668

669

Kana, T. M., C. Darkangelo, M. D. Hunt, and J. B. Oldham. 1994. Membrane inlet mass spectrometer for rapid high-precision determination of N2, O2, and Ar in environmental water samples. Analytical Chemistry 66:4166-4170.

Kellogg, M. L., A. R. Smyth, M. W. Luckenbach, R. H. Carmichael, B. L. Brown, J. C. Cornwell, M. F. Piehler, M. S. Owens, D. J. Dalrymple, and C. B. Higgins. 2014. Use of oysters to mitigate eutrophication in coastal waters. Estuarine, Coastal and Shelf Science $151: 156-168$.

Kellogg, M. L., J. C. Cornwell, M. S. Owens, and K. T. Paynter. 2013. Denitrification and nutrient assimilation on a restored oyster reef. Marine Ecology Progress Series 480:1-19.

Koop-Jakobsen, K., and A. E. Giblin. 2010. The effect of increased nitrate loading on nitrate reduction via denitrification and DNRA in salt marsh sediments. Limnology and Oceanography 55:789-802.

Langdon, C. J., and R. Newell. 1989. Utilization of detritus and bacteria as food sources by two bivalve suspension-feeders, the oyster Crassostrea virginica and the mussel Geukensia demissa. Marine Ecology Progress Series 58:299-310.

Lorenzen, C. J. 1967. Determination of chlorophyll and pheo-pigments: spectrophotometric equations. Limnology and Oceanography 12:343-346.

Lunstrum, A., and L. R. Aoki. 2016. Oxygen interference with membrane inlet mass spectrometry may overestimate denitrification rates calculated with the isotope pairing technique. Limnology and Oceanography: Methods 14:425-431.

Lunstrum, A., K. McGlathery, and A. Smyth. 2017. Oyster (Crassostrea virginica) aquaculture shifts sediment nitrogen processes toward mineralization over denitrification. Estuaries and Coasts. Accepted. 1-17.

Murphy, A. E., I. C. Anderson, A. R. Smyth, B. Song, and M. W. Luckenbach. 2016a. Microbial nitrogen processing in hard clam (Mercenaria mercenaria) aquaculture sediments: the relative importance of denitrification and dissimilatory nitrate reduction to ammonium (DNRA). Limnology and Oceanography 61:1589-1604.

Murphy, A. E., I. C. Anderson, and M. W. Luckenbach. 2015. Enhanced nutrient regeneration at commercial hard clam (Mercenaria mercenaria) beds and the role of macroalgae. Marine Ecology Progress Series 530:135-151.

Murphy, A. E., K. A. Emery, I. C. Anderson, M. L. Pace, M. J. Brush, and J. E. Rheuban. $2016 b$. Quantifying the Effects of Commercial Clam Aquaculture on $\mathrm{C}$ and $\mathrm{N}$ Cycling: an Integrated Ecosystem Approach. Estuaries and Coasts 39:1746-1761.

Newell, R. 2004. Ecosystem influences of natural and cultivated populations of suspensionfeeding bivalve molluscs: a review. Journal of Shellfish Research 23:51-61. 
Newell, R. I. E., J. C. Cornwell, and M. S. Owens. 2002. Influence of simulated bivalve biodeposition and microphytobenthos on sediment nitrogen dynamics: A laboratory study. Limnology and Oceanography 47:1367-1379.

Newell, R., T. R. Fisher, and R. R. Holyoke. 2005. Influence of eastern oysters on nitrogen and phosphorus regeneration in Chesapeake Bay, USA. in R. F. Dame and S. Olenin, editors. The Comparative Roles of Suspension-Feeders in Ecosystems.

Nielsen, L. 1992. Denitrification in sediment determined from nitrogen isotope pairing. FEMS Microbiology Letters 86:357-362.

Nizzoli, D., D. T. Welsh, and P. Viaroli. 2011. Seasonal nitrogen and phosphorus dynamics during benthic clam and suspended mussel cultivation. Marine Pollution Bulletin 62:12761287.

Nizzoli, D., D. T. Welsh, E. A. Fano, and P. Viaroli. 2006. Impact of clam and mussel farming on benthic metabolism and nitrogen cycling, with emphasis on nitrate reduction pathways.

Paerl, H. W. 1997. Coastal eutrophication and harmful algal blooms: Importance of atmospheric deposition and groundwater as "new" nitrogen and other nutrient sources. Limnology and Oceanography 42:1154-1165.

Pelegrí, S. P., and T. H. Blackburn. 1994. Bioturbation effects of the amphipod Corophium volutator on microbial nitrogen transformations in marine sediments. Marine Biology 121:253-258.

Piehler, M. F., and A. R. Smyth. 2011. Habitat-specific distinctions in estuarine denitrification affect both ecosystem function and services. Ecosphere 2:art12-16.

Pinckney, J., R. Papa, and R. Zingmark. 1994. Comparison of high-performance liquid chromatographic, spectrophotometric, and fluorometric methods for determining chlorophyll a concentrations in estuarine sediments. Journal of Microbiological Methods 19:59-66.

Qin, W., S. A. Amin, W. Martens-Habbena, C. B. Walker, H. Urakawa, A. H. Devol, A. E. Ingalls, J. W. Moffett, E. V. Armbrust, and D. A. Stahl. 2014. Marine ammonia-oxidizing archaeal isolates display obligate mixotrophy and wide ecotypic variation. Proceedings of the National Academy of Sciences 111:12504-12509.

Reeburgh, W. S. 1969. Observations of Gases in Chesapeake Bay Sediments. Limnology and Oceanography 14:368-375.

Risgaard-Petersen, N., N. P. Revsbech, and S. Rysgaard. 1995. Combined MicrodiffusionHypobromite Oxidation Method for Determining Nitrogen-15 Isotope in Ammonium. Soil Science Society of America Journal 59:1077-1080. 
Roberts, K. L., V. M. Eate, B. D. Eyre, D. P. Holland, and P. L. M. Cook. 2012. Hypoxic events stimulate nitrogen recycling in a shallow salt-wedge estuary: The Yarra River estuary, Australia. Limnology and Oceanography 57:1427-1442.

Rose, J. M., S. B. Bricker, and J. G. Ferreira. 2014. Comparative analysis of modeled nitrogen removal by shellfish farms. Marine Pollution Bulletin 91:1-6.

Safak, I., P. L. Wiberg, D. L. Richardson, and M. O. Kurum. 2015. Controls on residence time and exchange in a system of shallow coastal bays. Continental Shelf Research 97:7-20.

Secrist, R. G. 2013. Food availability and utilization for cultured hard clams. Thesis. The College of William and Mary, Gloucester Point, VA, USA

Sloth, N. P., H. Blackburn, L. S. Hansen, N. Risgaard-Petersen, and B. A. Lomstein. 1995. Nitrogen cycling in sediments with different organic loading. Oceanographic Literature Review 9:733.

Smyth, A. R., M. F. Piehler, and J. H. Grabowski. 2015. Habitat context influences nitrogen removal by restored oyster reefs. Journal of Applied Ecology 52:716-725.

Smyth, A. R., N. R. Geraldi, and M. F. Piehler. 2013a. Oyster-mediated benthic-pelagic coupling modifies nitrogen pools and processes. Marine Ecology Progress Series 493:23-30.

Smyth, A. R., N. R. Geraldi, S. P. Thompson, and M. F. Piehler. 2016. Biological activity exceeds biogenic structure in influencing sediment nitrogen cycling in experimental oyster reefs. Marine Ecology Progress Series 560:173-183.

Smyth, A. R., S. P. Thompson, K. N. Siporin, W. S. Gardner, M. J. McCarthy, and M. F. Piehler. 2013b. Assessing nitrogen dynamics throughout the estuarine landscape. Estuaries and Coasts 36:44-55.

Stief, P. 2013. Stimulation of microbial nitrogen cycling in aquatic ecosystems by benthic macrofauna: mechanisms and environmental implications. Biogeosciences 10:7829-7846.

Tiedje, J. M. 1988. Ecology of denitrification and dissimilatory nitrate reduction to ammonium. Biology of anaerobic microorganisms.

Turek, K. A., and T. J. Hoellein. 2015. The invasive Asian clam ( Corbicula fluminea) increases sediment denitrification and ammonium flux in 2 streams in the midwestern USA. Freshwater Science 34:472-484.

Welsh, D. T. 2003. It's a dirty job but someone has to do it: The role of marine benthic macrofauna in organic matter turnover and nutrient recycling to the water column. Chemistry and Ecology 19:321-342.

Welsh, D. T., and G. Castadelli. 2004. Bacterial nitrification activity directly associated with isolated benthic marine animals. Marine Biology 144:1029-1037. 
738

739

740

741

742

743

744
Welsh, D. T., D. Nizzoli, E. A. Fano, and P. Viaroli. 2015. Direct contribution of clams (Ruditapes philippinarum) to benthic fluxes, nitrification, denitrification and nitrous oxide emission in a farmed sediment. Estuarine, Coastal and Shelf Science 154:84-93.

Yin, G., L. Hou, M. Liu, Z. Liu, and W. S. Gardner. 2014. A Novel Membrane Inlet Mass Spectrometer Method to Measure 15NH 4+for Isotope-Enrichment Experiments in Aquatic Ecosystems. Environmental Science \& Technology 48:9555-9562. 


\section{Figure Captions}

Figure 1: Image of Smith Island Bay, Chesapeake Bay, US. Locations of clam beds (triangle), oyster reefs (square) and bare sediment (circle) are identified.

Figure 2: Actual denitrification $\left(\mathrm{D}_{14}\right)(\mathrm{A})$ and DNRA $\left(\mathrm{DNRA}_{14}\right)(\mathrm{B})$ rates for each site and season. Direct denitrification $\left(\mathrm{D}_{\mathrm{w}}\right)$ or DNRA $\left(\mathrm{DNRA}_{\mathrm{w}}\right)$ are in black and denitrification or DNRA coupled to nitrification $\left(\mathrm{D}_{\mathrm{n}}\right.$, or $\left.\mathrm{DNRA}_{\mathrm{n}}\right)$ is presented in gray. Error bars are on standard error of the mean $(n=3)$.

Figure 3: Potential denitrification $\left(D_{15}\right)(A)$ and DNRA $\left.\left(D_{N R A}\right)_{15}\right)(B)$ rates for each site and season. Error bars are on standard error of the mean $(n=3)$.

Figure 4: Regression of Total Ambient $\mathrm{NO}_{3}{ }^{-}$reduction (A), nitrification (B) and $\mathrm{NH}_{4}{ }^{+}$flux (C) against SOD. Pearson correlation coefficient, regression equation, $\mathrm{r}^{2}$, and $\mathrm{p}$-value for the relationship, which includes all the data for each site and season, and are included on each graph. Samples from the clam bed are identified as triangles, oyster reef sediments are squares and bare sediment are circles.

Figure 5: Regression of $\mathrm{D}_{14}(\mathrm{~A})$ and $\mathrm{DNRA}_{14}$ (B) against sediment organic matter (SOM). Pearson correlation coefficient, regression equation, $r^{2}$, and $p$-value for the relationship, which includes all the data for each site and season, and are included on each graph. Samples from the clam bed are identified as triangles, oyster reef sediments are squares and bare sediment are circles. 

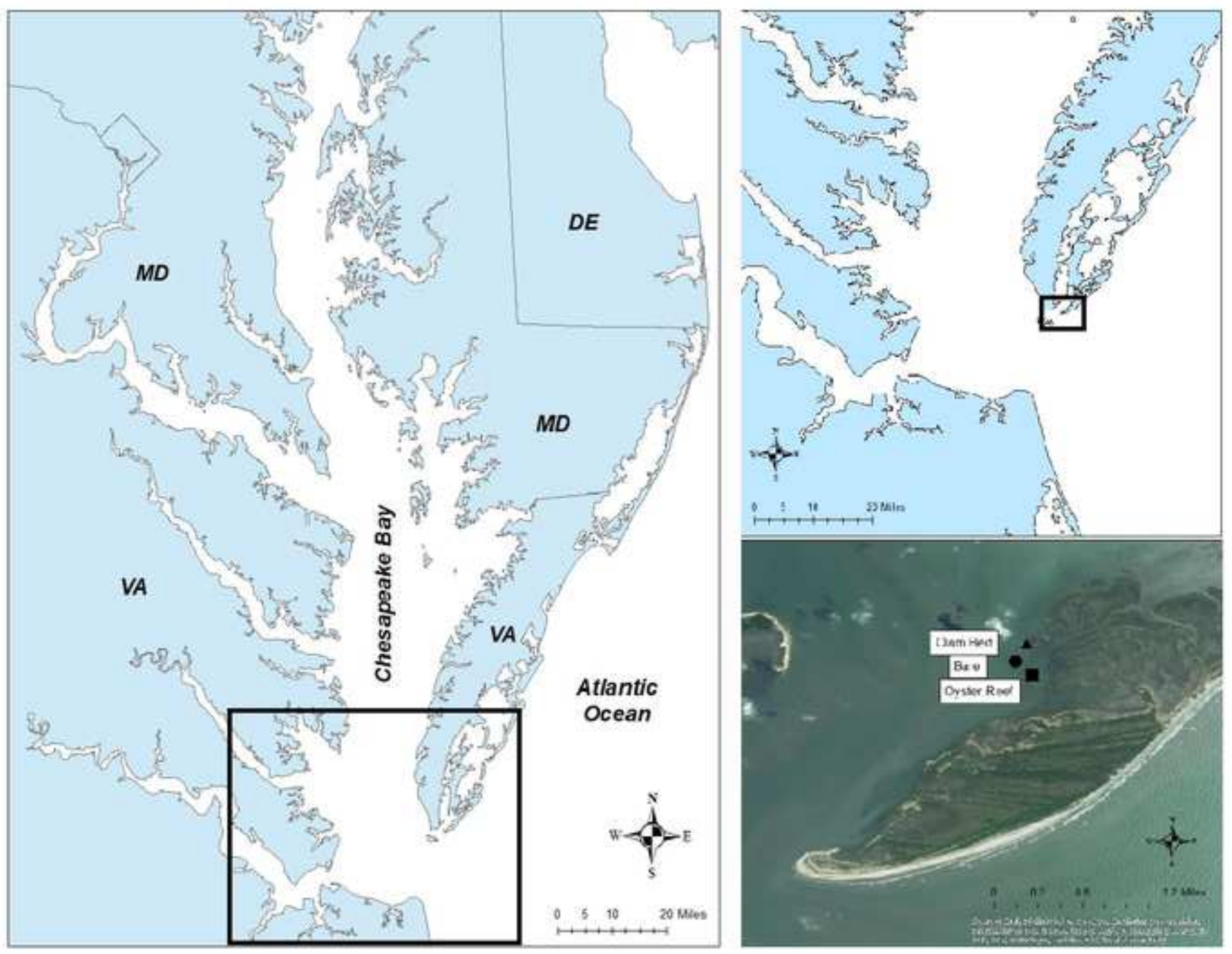


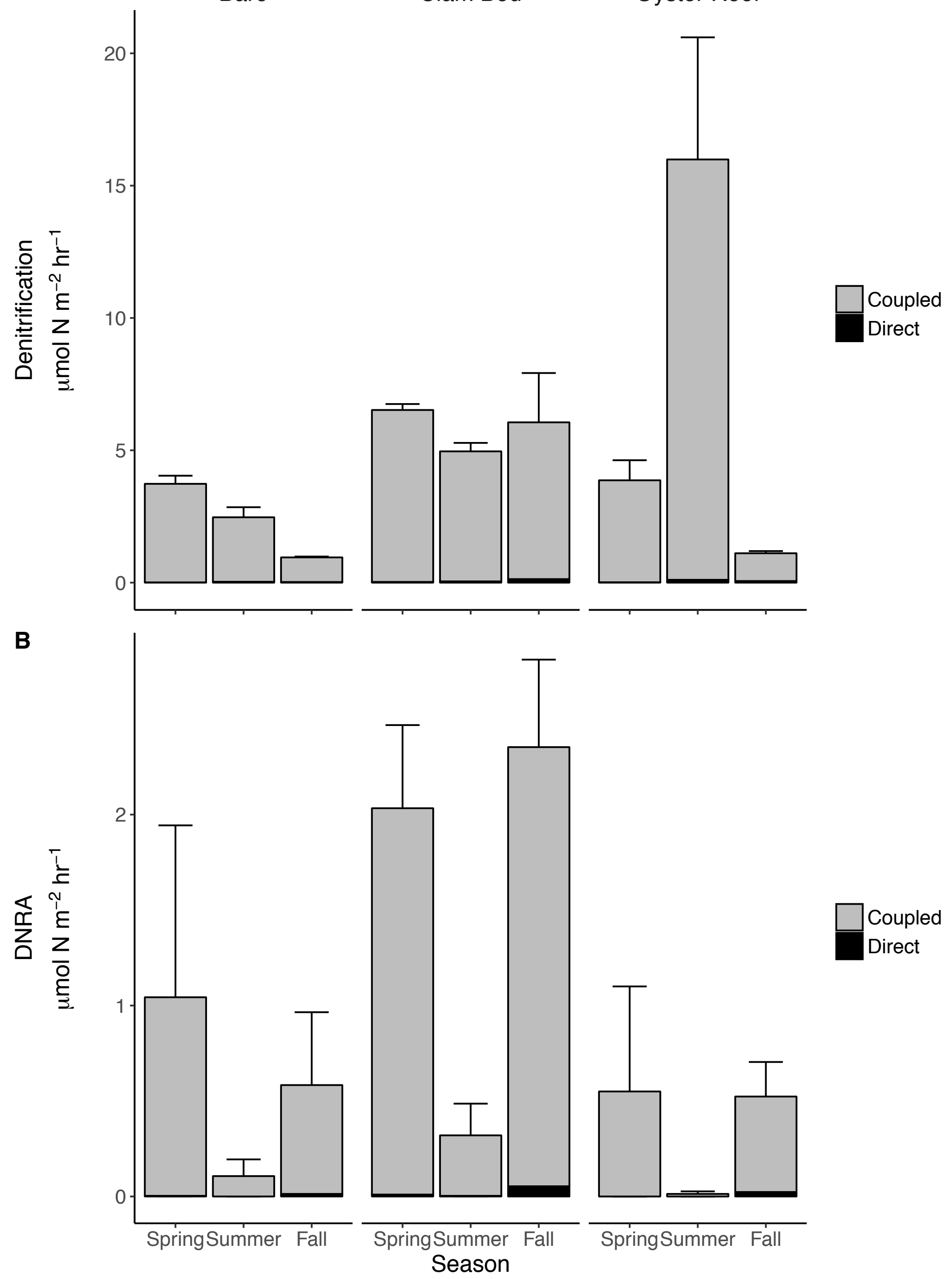




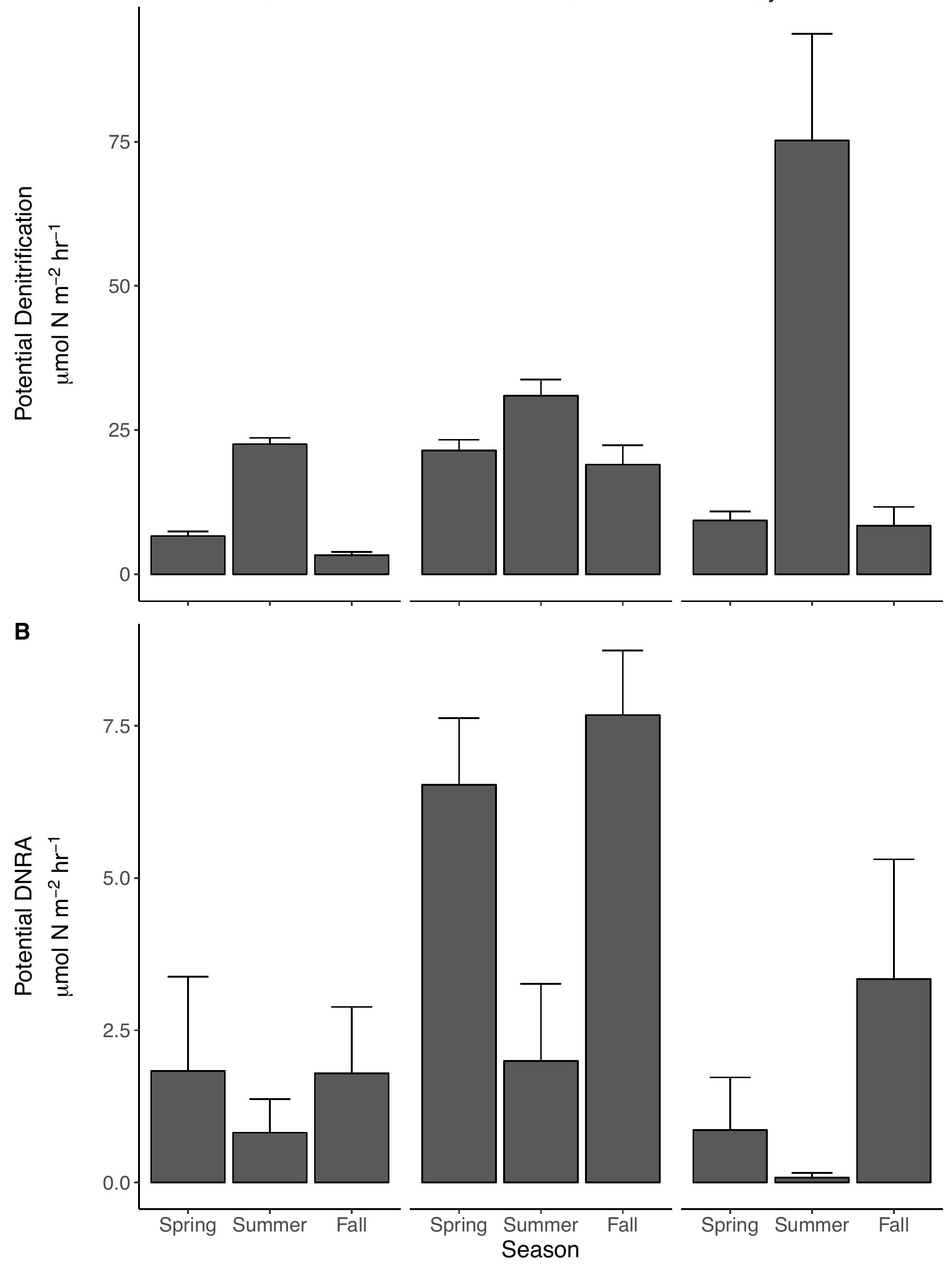




\section{Bare $\mathbf{A}$ Clam Bed $\mathbf{a}$ Oyster Reef}
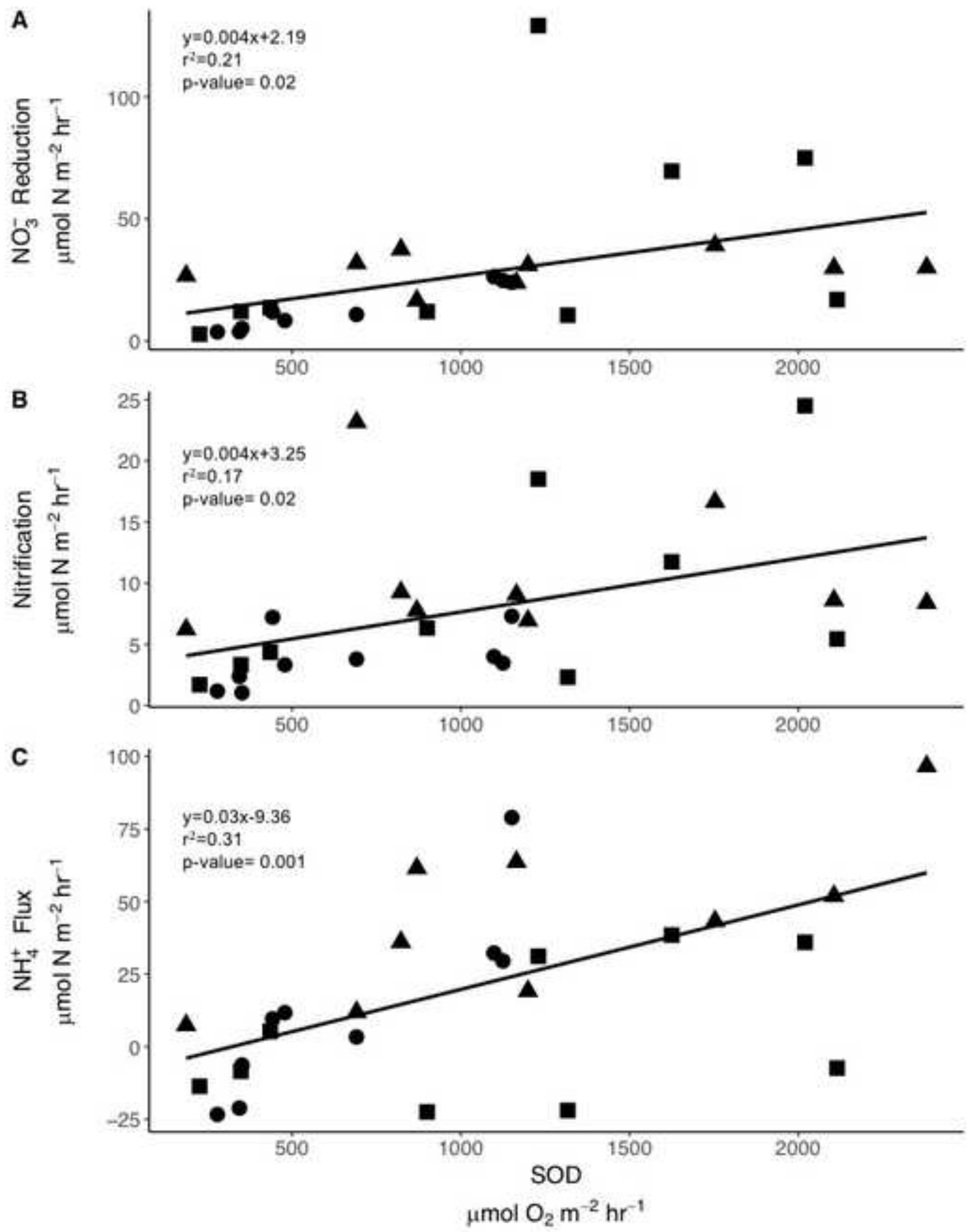


\section{Bare $\boldsymbol{\Delta}$ Clam Bed $\mathbf{a}$ Oyster Reef}

A

$y=11.04 x-4.26$

$r^{2}=0.20$

p-value $=0.02$

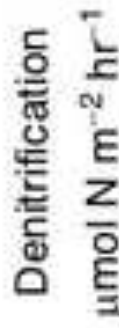

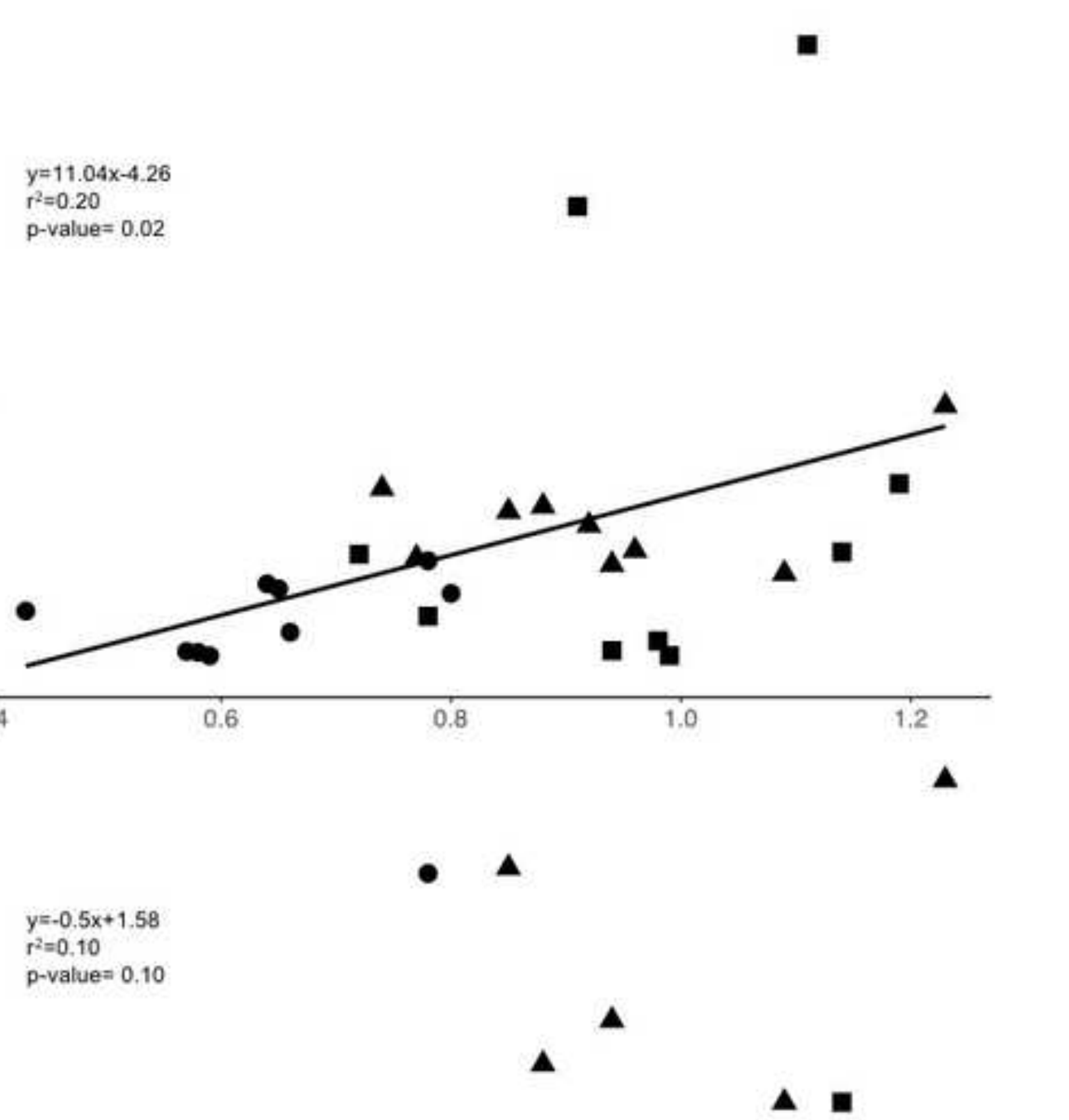

0

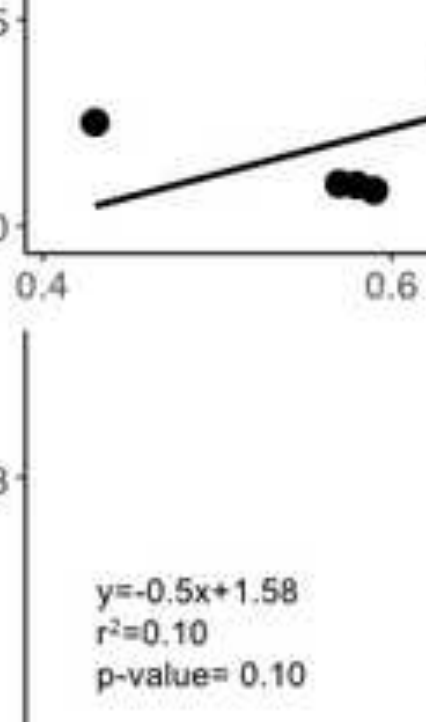

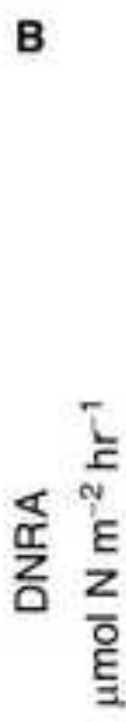

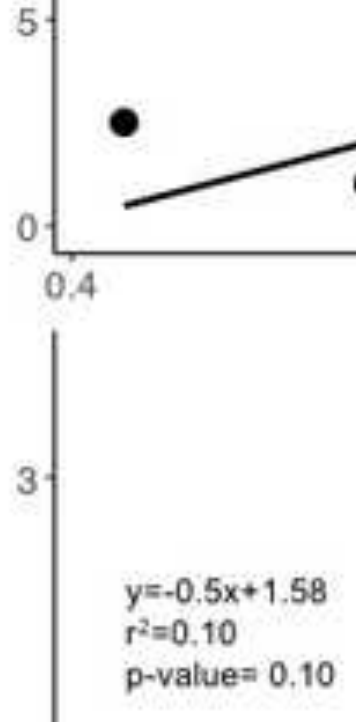

21

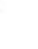
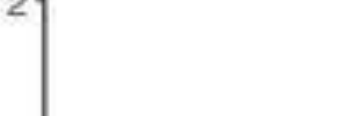

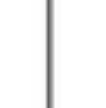

1

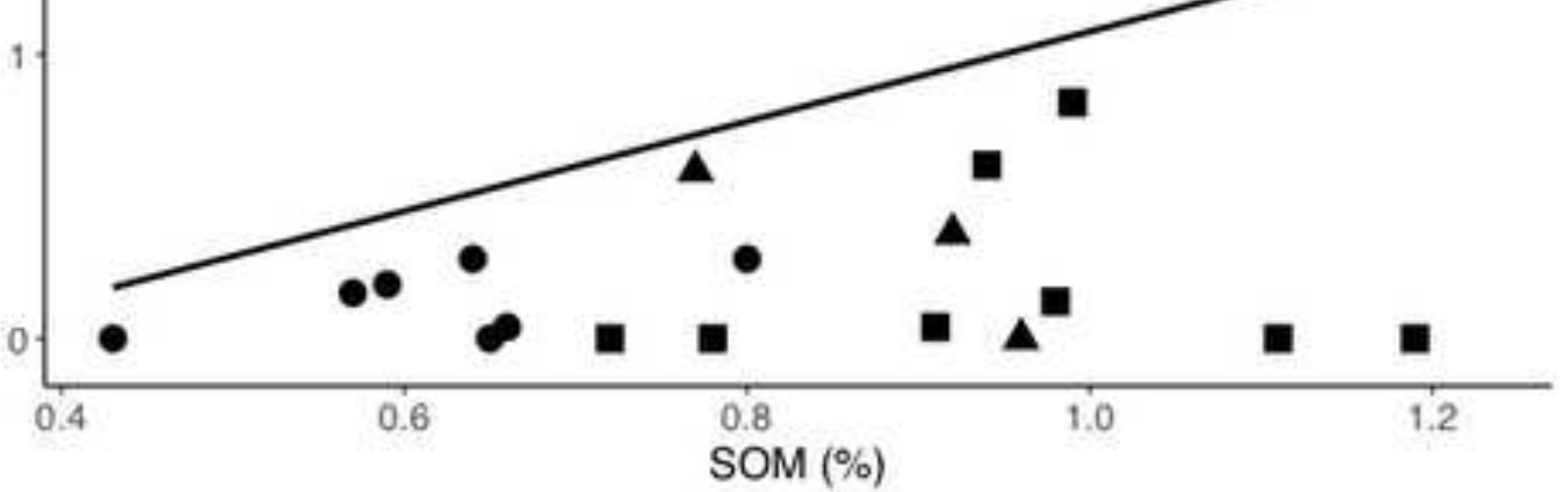

A
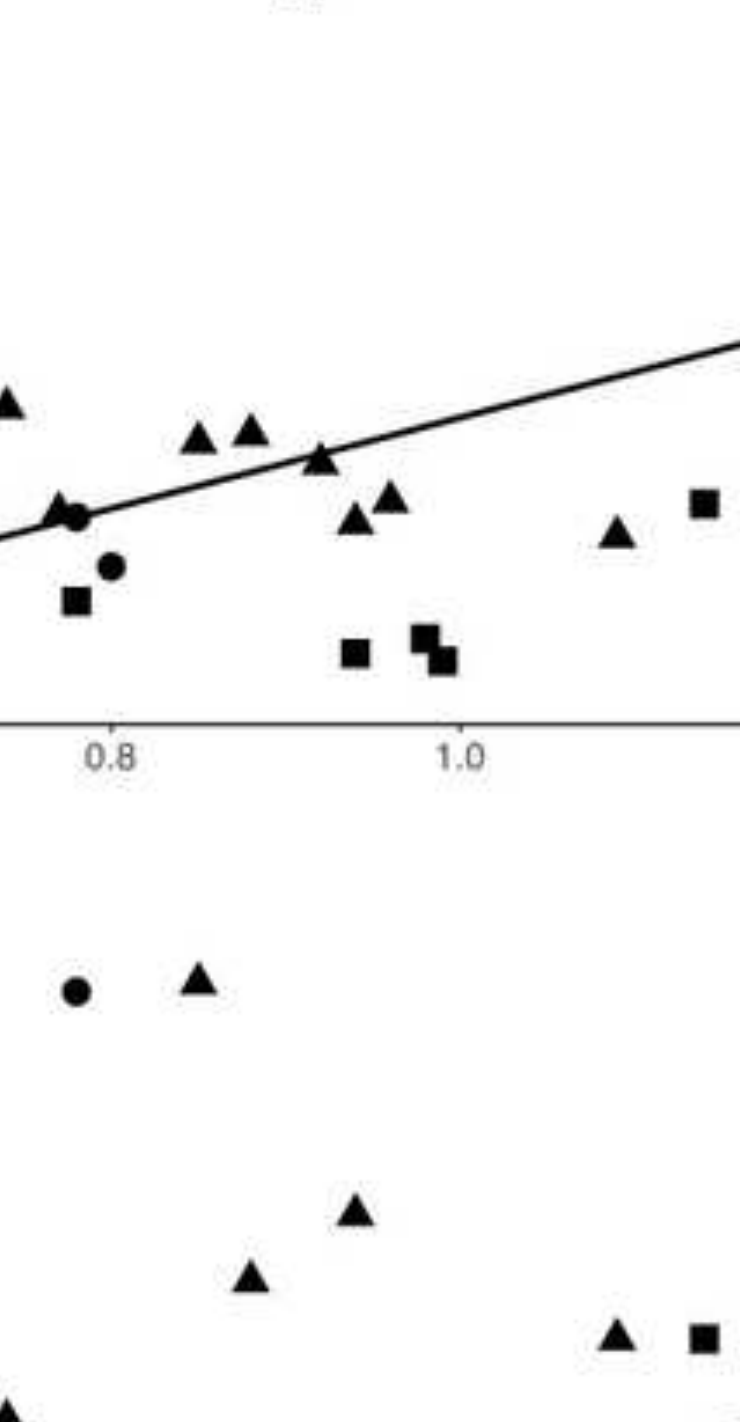

$(\%)$ 
Table 1: Reported rates of denitrification and DNRA measured from the eastern oyster (Crassostrea virginica) or hard clam (Mercenaria mercenaria) ecosystems using either the $\mathrm{N}_{2}$ :Ar method or Isotope Pairing Technique (IPT).

\begin{tabular}{|c|c|c|c|c|c|c|c|c|}
\hline Bivalve Species & Context & 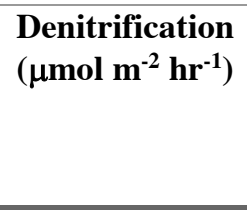 & $\begin{array}{l}\text { DNRA } \\
\left(\mu \mathrm{mol} \mathrm{m} \mathbf{m}^{-2} \mathbf{h r}^{-1}\right)\end{array}$ & $\begin{array}{l}\text { Denitrification } \\
\text { increased } \\
\text { above Bare } \\
\text { Sediment } \\
\text { Site? }\end{array}$ & $\begin{array}{c}\text { DNRA } \\
\text { increased } \\
\text { above Bare } \\
\text { Sediment } \\
\text { Site? }\end{array}$ & Location & Methods & Reference \\
\hline $\begin{array}{l}\text { Mercenaria } \\
\text { mercenaria } \\
\text { (hard clam) }\end{array}$ & Aquaculture & $0.77-2.9$ & $2.7-14.2$ & $\begin{array}{c}\text { Only in the } \\
\text { Fall }\end{array}$ & $\begin{array}{c}\text { Yes, all } \\
\text { seasons }\end{array}$ & $\begin{array}{l}\text { Shallow polyhaline } \\
\text { sediments } \\
\text { (Cherrystone Inlet, } \\
\text { VA) }\end{array}$ & $\begin{array}{l}\text { Whole core batch } \\
\text { incubation; isotope } \\
\text { pairing technique }\end{array}$ & $\begin{array}{l}\text { Murphy et al., } \\
2016\end{array}$ \\
\hline $\begin{array}{l}\text { Mercenaria } \\
\text { mercenaria } \\
\text { (hard clam) }\end{array}$ & Aquaculture & $4.9-6.5$ & $0.32-2.36$ & Yes & No & $\begin{array}{l}\text { Shallow coastal bay } \\
\text { (Smith Island Bay, } \\
\text { VA) }\end{array}$ & $\begin{array}{l}\text { Whole core } \\
\text { continuous-flow } \\
\text { incubation; isotope } \\
\text { pairing technique }\end{array}$ & This Study \\
\hline $\begin{array}{l}\text { Crassostrea } \\
\text { virginica } \\
\text { (eastern oyster) }\end{array}$ & Aquaculture & $0-65$ & --- & No & --- & $\begin{array}{l}\text { Shallow mesohaline } \\
\text { sediments below } \\
\text { floats (St. Jerome } \\
\text { Creek and Spencer } \\
\text { Creek. VA) }\end{array}$ & $\begin{array}{l}\text { Whole core } \\
\text { continuous-flow } \\
\text { incubation; } \mathrm{N}_{2}: \mathrm{Ar} \\
\text { Technique }\end{array}$ & $\begin{array}{l}\text { Higgins et al., } \\
2013\end{array}$ \\
\hline $\begin{array}{l}\text { Crassostrea } \\
\text { virginica } \\
\text { (eastern oyster) }\end{array}$ & Aquaculture & $0-1097$ & --- & Yes & --- & $\begin{array}{l}\text { Back barrier lagoon } \\
\text { (Ninigret Pond, RI) }\end{array}$ & $\begin{array}{l}\text { Whole chamber batch } \\
\text { incubations; } \mathrm{N}_{2}: \mathrm{Ar} \\
\text { Technique }\end{array}$ & $\begin{array}{l}\text { Humphries et al., } \\
2016\end{array}$ \\
\hline $\begin{array}{l}\text { Crassostrea } \\
\text { virginica } \\
\text { (eastern oyster) }\end{array}$ & Aquaculture & $-4.7-12.1$ & --- & No & --- & $\begin{array}{l}\text { Shallow subtropical } \\
\text { estuary below floats } \\
\text { (Mobile Bay, AL) }\end{array}$ & $\begin{array}{l}\text { Whole core } \\
\text { continuous-flow } \\
\text { incubation; } \mathrm{N}_{2}: \mathrm{Ar}\end{array}$ & $\begin{array}{l}\text { Mortazavi et al. } \\
2015\end{array}$ \\
\hline $\begin{array}{l}\text { Crassostrea } \\
\text { virginica } \\
\text { (eastern oyster) }\end{array}$ & Aquaculture & $<1-19.2$ & $<1$ to 40.3 & Yes & Yes & $\begin{array}{l}\text { Shallow polyhaline } \\
\text { sediments } \\
\text { (Cherrystone Inlet, } \\
\text { VA) }\end{array}$ & $\begin{array}{l}\text { Whole core batch } \\
\text { incubation; isotope } \\
\text { pairing technique }\end{array}$ & $\begin{array}{l}\text { Lunstrum et al. } \\
2017\end{array}$ \\
\hline $\begin{array}{l}\text { Crassostrea } \\
\text { virginica } \\
\text { (eastern oyster) }\end{array}$ & Restored Reef & $250-1590$ & --- & Yes & --- & $\begin{array}{l}\text { Mesohaline subtidal } \\
\text { reef (Choptank } \\
\text { River, MD) }\end{array}$ & $\begin{array}{l}\text { Whole chamber batch } \\
\text { incubations; } \mathrm{N}_{2}: \mathrm{Ar} \\
\text { Technique }\end{array}$ & $\begin{array}{l}\text { Kellogg et al., } \\
2013\end{array}$ \\
\hline
\end{tabular}




\begin{tabular}{|c|c|c|c|c|c|c|c|c|}
\hline $\begin{array}{l}\text { Crassostrea } \\
\text { virginica } \\
\text { (eastern oyster) }\end{array}$ & Restored Reef & $0-332$ & $0.8-104$ & Yes & $\begin{array}{l}\text { Yes, in the } \\
\text { summer }\end{array}$ & $\begin{array}{l}\text { Intertidal sediments } \\
\text { adjacent to reef } \\
\text { (Bogue Sound, NC) }\end{array}$ & $\begin{array}{l}\text { Whole core } \\
\text { continuous-flow } \\
\text { incubation; } \mathrm{N}_{2} \text { :Ar; } \\
\text { then }{ }^{15} \mathrm{NO}_{3}{ }^{-} \text {for } \\
\text { potential DNRA } \\
\text { measurements }\end{array}$ & Smyth et al., 2013b \\
\hline $\begin{array}{l}\text { Crassostrea } \\
\text { virginica } \\
\text { (eastern oyster) }\end{array}$ & Restored Reef & $0-1803$ & --- & Yes & --- & $\begin{array}{l}\text { Back barrier lagoon } \\
\text { (Ninigret Pond, RI) }\end{array}$ & $\begin{array}{l}\text { Whole chamber batch } \\
\text { incubations; } \mathrm{N}_{2}: A r \\
\text { Technique }\end{array}$ & $\begin{array}{l}\text { Humphries et al. } \\
2016\end{array}$ \\
\hline $\begin{array}{l}\text { Crassostrea } \\
\text { virginica } \\
\text { (eastern oyster) }\end{array}$ & Restored Reef & $1.1-16.0$ & $0.01-0.55$ & Yes & No & $\begin{array}{l}\text { Shallow coastal bay } \\
\text { (Smith Island Bay, } \\
\text { VA) }\end{array}$ & $\begin{array}{l}\text { Whole core } \\
\text { continuous-flow } \\
\text { incubation; isotope } \\
\text { pairing technique }\end{array}$ & This Study \\
\hline $\begin{array}{l}\text { Crassostrea } \\
\text { virginica } \\
\text { (eastern oyster) }\end{array}$ & Natural Reefs & $10-30$ & --- & $\begin{array}{l}\text { Yes, enriched } \\
\text { location only }\end{array}$ & --- & $\begin{array}{l}\text { Intertidal sediments } \\
\text { adjacent to reef in an } \\
\text { enriched and } \\
\text { reference streams } \\
\text { (Great Bay Estuary, } \\
\text { NH) }\end{array}$ & $\begin{array}{l}\text { Whole core } \\
\text { continuous-flow } \\
\text { incubation with } \\
{ }^{15} \mathrm{NO}_{3}{ }^{-} \text {addition }\end{array}$ & $\begin{array}{l}\text { Hoellein et al. } \\
2015\end{array}$ \\
\hline
\end{tabular}


Table 2: In situ water properties at each sampling date. Mean and standard error $(n=3)$ are presented for water column nutrients. $\mathrm{BD}=$ Below Detection.

\begin{tabular}{ccccccc}
\hline Season & Date & $\begin{array}{c}\text { Temp } \\
\left({ }^{\circ} \mathbf{C}\right)\end{array}$ & Salinity & $\begin{array}{c}\text { Dissolved } \\
\text { Oxygen } \\
(\mathbf{m g} / \mathbf{l}) \\
{[\mathbf{O} \%]}\end{array}$ & $\begin{array}{c}\mathbf{N O}_{\mathbf{x}} \\
(\boldsymbol{\mu M})\end{array}$ & $\begin{array}{c}\mathbf{N H}_{4}{ }^{+} \\
(\boldsymbol{\mu M})\end{array}$ \\
\hline Spring & 24-Apr-14 & 15.6 & 33 & $\begin{array}{c}8.05 \\
{[98.1 \%]}\end{array}$ & BD & $3.06 \pm 0.04$ \\
Summer & 23-Jun-14 & 25 & 30.5 & $\begin{array}{c}6.36 \\
{[91.5 \%]}\end{array}$ & BD & $0.46 \pm 0.01$ \\
Fall & 5-Nov-15 & 14 & 31.7 & $\begin{array}{c}8.28 \\
{[96.8 \%]}\end{array}$ & $0.72 \pm 0.01$ & $1.76 \pm 0.04$ \\
\hline
\end{tabular}


Table 3: Seasonal sediment characteristics for each site and sampling date for all parameters. $\mathrm{H}_{2} \mathrm{~S}$ in the clam bed in spring, bare sediment in summer and oyster reef in fall only had one sample above the detection limit. Data are mean \pm standard error (SE) for all parameters. NA for SE indicates that only one sample was above the detection limit. Letters indicate significant differences between the means.

\begin{tabular}{|c|c|c|c|c|c|c|c|c|c|c|c|c|}
\hline \multirow[b]{2}{*}{ Spring } & \multirow[b]{2}{*}{ Bare } & \multicolumn{2}{|c|}{$\begin{array}{c}\text { SOM } \\
(\%)\end{array}$} & \multicolumn{2}{|c|}{$\begin{array}{c}\text { Benthic Chl } \\
\left(\mu \mathrm{g} / \mathrm{cm}^{2}\right)\end{array}$} & \multicolumn{2}{|c|}{$\begin{array}{c}\mathrm{H}_{2} \mathrm{~S} \\
(\mu \mathrm{M})\end{array}$} & \multicolumn{2}{|c|}{$\begin{array}{c}\text { Porewater } \\
\text { NOx } \\
(\mu \mathrm{M})\end{array}$} & \multicolumn{3}{|c|}{$\begin{array}{c}\text { Porewater } \\
\mathrm{NH}_{4}^{+} \\
(\mu \mathrm{M})\end{array}$} \\
\hline & & 0.69 & \pm 0.05 & 0.41 & \pm 0.03 & 25.74 & $\pm \quad 5.55$ & 0.62 & \pm 0.18 & 70.73 & \pm & 12.67 \\
\hline & Clam Bed & 0.82 & \pm 0.04 & 0.80 & \pm 0.08 & 2.20 & NA & 0.39 & \pm 0.07 & 187.89 & \pm & 25.82 \\
\hline & $\begin{array}{l}\text { Oyster } \\
\text { Reef }\end{array}$ & 0.88 & \pm 0.13 & 0.74 & \pm 0.07 & 33.97 & \pm 11.04 & 0.36 & \pm 0.02 & 24.34 & \pm & 10.12 \\
\hline \multirow[t]{3}{*}{ Summer } & Bare & 0.63 & \pm 0.11 & 2.11 & \pm 0.19 & 10.89 & NA & 0.56 & \pm 0.04 & 51.40 & \pm & 11.29 \\
\hline & Clam Bed & 0.88 & \pm 0.06 & 1.47 & \pm 0.09 & 265.81 & \pm 99.27 & 0.92 & \pm 0.22 & 184.76 & \pm & 28.30 \\
\hline & $\begin{array}{l}\text { Oyster } \\
\text { Reef }\end{array}$ & 1.07 & \pm 0.08 & 1.30 & \pm 0.52 & 228.20 & \pm 115.04 & 0.65 & \pm 0.06 & 121.59 & \pm & 67.31 \\
\hline \multirow[t]{3}{*}{ Fall } & Bare & 0.58 & \pm 0.01 & 5.54 & \pm 0.45 & 11.11 & 3.59 & 0.49 & \pm 0.09 & 52.34 & \pm & 14.48 \\
\hline & Clam Bed & 1.09 & \pm 0.09 & 7.37 & \pm 0.43 & 53.28 & \pm 17.68 & 0.96 & \pm 0.60 & 102.98 & \pm & 12.98 \\
\hline & $\begin{array}{l}\text { Oyster } \\
\text { Reef }\end{array}$ & 0.97 & \pm 0.02 & 3.69 & \pm 0.19 & 4.72 & NA & 0.50 & \pm 0.03 & 42.63 & \pm & 13.96 \\
\hline \multirow[t]{3}{*}{ Mean } & Bare & 0.63 & \pm 0.04 & 2.69 & \pm 0.77 & 15.95 & $\pm \quad 3.90$ & 0.56 & \pm 0.06 & 58.16 & \pm & 7.17 \\
\hline & Clam Bed & 0.93 & \pm 0.05 & 3.22 & \pm 1.05 & 137.07 & \pm 59.76 & 0.76 & \pm 0.21 & 158.5 & \pm & 18.15 \\
\hline & $\begin{array}{l}\text { Oyster } \\
\text { Reef }\end{array}$ & 0.97 & \pm 0.05 & 1.91 & \pm 0.48 & 93.84 & \pm 56.34 & 0.52 & \pm 0.05 & 67.67 & \pm & 26.13 \\
\hline
\end{tabular}


Table 4: Seasonal mean $(n=3)$ fluxes of ammonium $\left(\mathrm{NH}_{4}^{+}\right)$, nitrate+nitrite $\left(\mathrm{NO}_{\mathrm{x}}{ }^{-}\right)$, calculated nitrification and sediment oxygen demand (SOD). Data are mean \pm SE for all parameters.

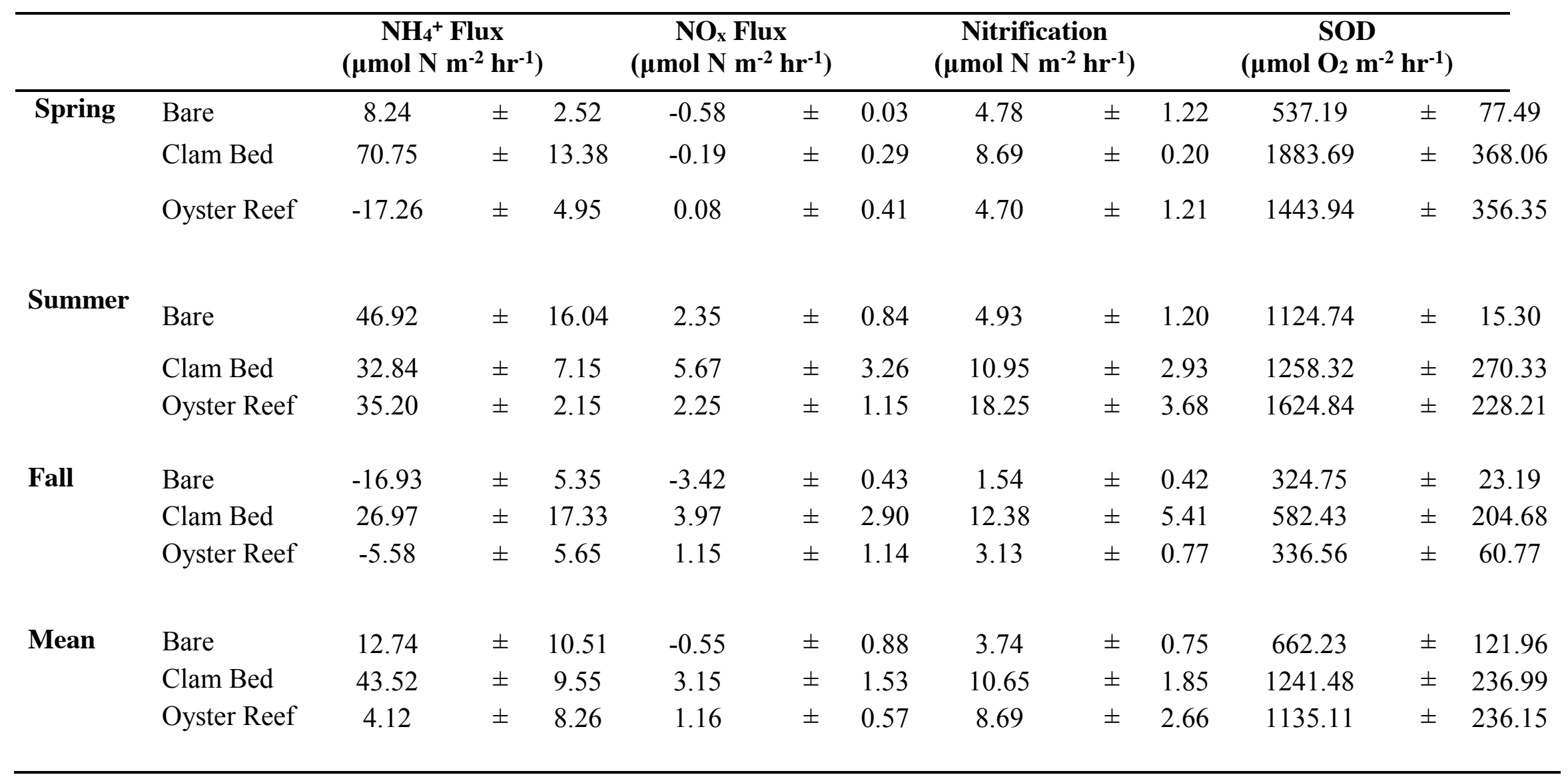



Supplemental Table 1: Number of clams per core by season.

\begin{tabular}{ccc}
\hline Season & Core ID & Number of Clams \\
\hline Spring & Clam Bed-1 & 4 \\
Spring & Clam Bed-2 & 3 \\
Spring & Clam Bed-3 & 4 \\
Summer & Clam Bed-1 & 0 \\
Summer & Clam Bed-2 & 0 \\
Summer & Clam Bed-3 & 0 \\
Fall & Clam Bed-1 & 4 \\
Fall & Clam Bed-2 & 4 \\
Fall & Clam Bed-3 & 4
\end{tabular}

